Maurício Rodrigues Jordão

\title{
Efeitos da simpatectomia no miocárdio
}

Tese apresentada à Faculdade de Medicina da Universidade de São Paulo para obtenção do título de Doutor em Ciências

Programa de Cardiologia

Orientador: Prof. Dr. Felix José Alvarez Ramires

São Paulo

2017 
Dados Internacionais de Catalogação na Publicação (CIP)

Preparada pela Biblioteca da

Faculdade de Medicina da Universidade de São Paulo

Creprodução autorizada pelo autor

Jordão, Maurício Rodrigues

Efeitos da simpatectomia no miocárdio / Maurício Rodrigues Jordão. -- São Paulo, 2017.

Tese(doutorado)--Faculdade de Medicina da Universidade de São Paulo. Programa de Cardiologia.

Orientador: Felix José Alvarez Ramires.

Descritores: 1.Simpatectomia 2.Sistema nervoso autônomo 3.Miocárdio

USP/FM/DBD-142/17 


\section{DEDICATÓRIA}


Á minha família 
AGRADECIMENTOS 
Ao meu orientador, Prof. Dr. Felix José Alvarez Ramires, cardiologista e amigo, por ter me recebido de braços abertos e ser presente em vários projetos profissionais além deste. Minha admiração, gratidão e respeito, por toda sua dedicação e, sobretudo, paciência.

Aos amigos Orlando Ribeiro, Keila Fonseca e Fernanda G. Pessoa por participar em momentos decisivos deste trabalho que foram fundamentais para o sucesso desta tese.

À família Cardio Geral, Profa. Dra. Bárbara Maria lanni, Prof. Dr. Edmundo Arteaga Fernandez, Prof. Dr. Fábio Fernandes, Dr. André Luiz Dabarian, Dr. Ricardo Ribeiro Dias, Dr. Luciano Nastari, Dra. Paula Buck, Roseli Chaves pela acolhida afetuosa, dedicação e momentos felizes que tive o privilégio de fazer parte durante esses anos.

Ao Prof. Dr. Charles Mady, pelos conselhos científicos e profissionais, meu respeito e admiração.

À Profa. Dra. Vera Maria Cury Salemi pelo auxílio com os ecocardiogramas.

À amiga Lucia Maria de Oliveira pelo empenho e trabalho essencial na disposição final desta tese.

Aos colegas Fernando Zanoni, Rafael Dantas, Leandro E. Souza e Fernando dos Santos pelo auxílio nos procedimentos experimentais e análises de dados.

À FAPESP (Fundação de Amparo a Pesquisa do Estado de São Paulo) pelo suporte financeiro deste projeto que possibilitou a execução dessa tese. 
"A dúvida não é uma condição agradável, mas a certeza é absurda."

Voltaire 
Esta dissertação ou tese está de acordo com as seguintes normas, em vigor no momento desta publicação:

Referências: adaptado de International Committee of Medical Journals Editors (Vancouver).

Universidade de São Paulo. Faculdade de Medicina. Divisão de Biblioteca e Documentação. Guia de apresentação de dissertações, teses e monografias. Elaborado por Anneliese Carneiro da Cunha, Maria Julia de A. L. Freddi, Maria F. Crestana, Marinalva de Souza Aragão, Suely Campos Cardoso, Valéria Vilhena. $3^{a}$ ed. São Paulo: Divisão de Biblioteca e Documentação; 2011.

Abreviaturas dos títulos dos periódicos de acordo com List of Journals Indexed in Index Medicus. 


\title{
SUMÁRIO
}

\author{
LISTA DE ABREVIATURAS E SIGLAS \\ LISTA DE FIGURAS E TABELAS \\ RESUMO \\ ABSTRACT
}

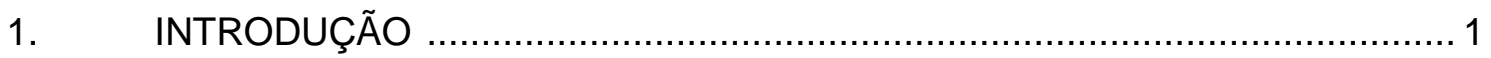

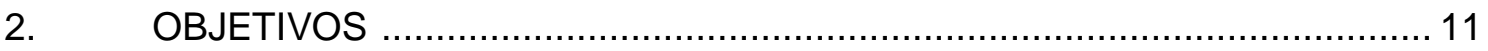

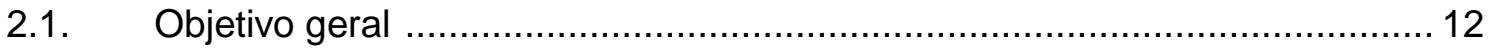

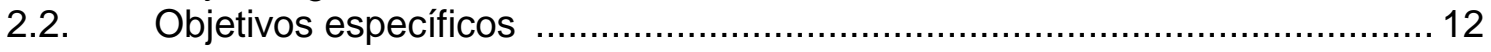

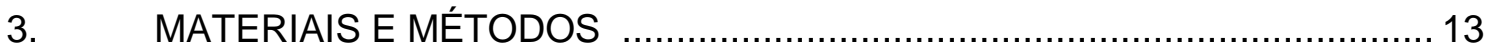

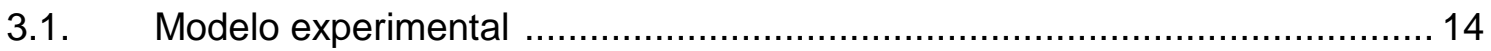

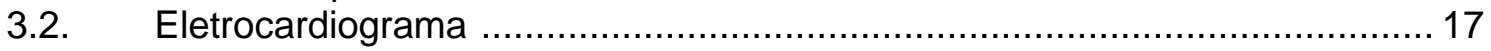

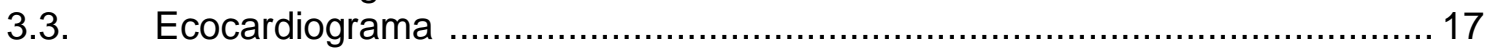

3.4. Avaliação da modulação autonômica cardiovascular .................................. 18

3.5. Teste de esforço máximo aeróbio .......................................................... 19

3.6. Análise da atividade simpática ................................................................ 20

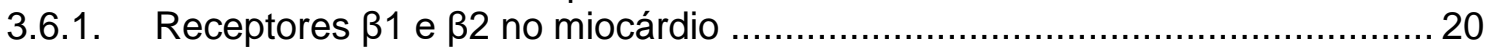

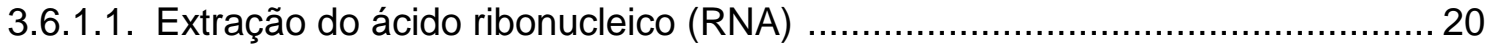

3.6.1.2. Tratamento do RNA total com a enzima DNase free .................................22

3.6.1.3. Transcrição reversa (síntese de DNA complementar (cDNA)) ....................... 22

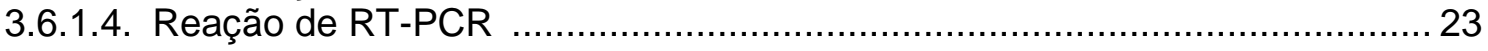

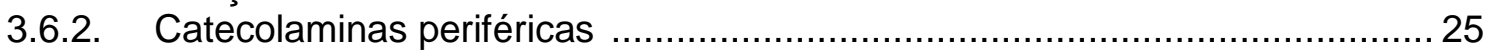

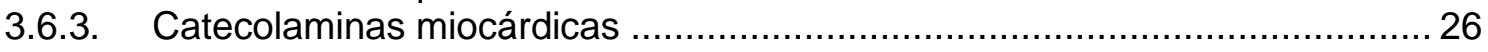

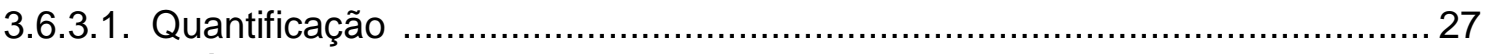

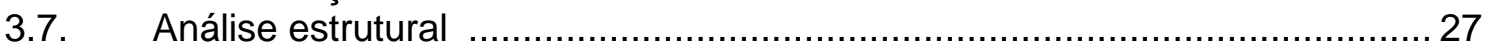

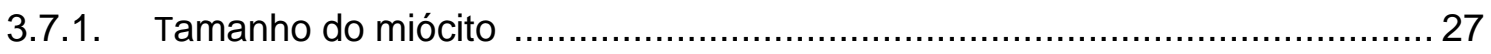

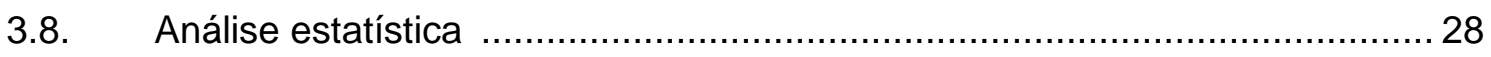

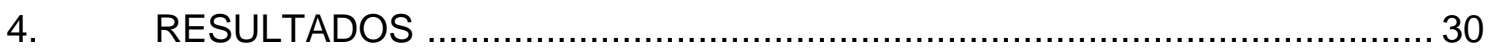

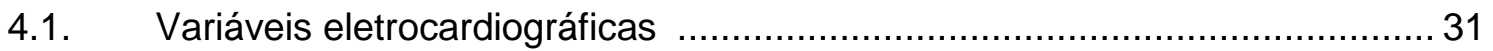

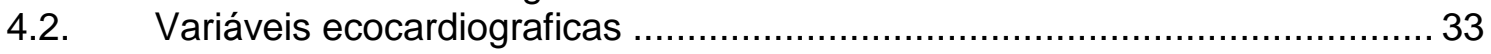

4.3. Análises da modulação autonômica ............................................................ 34

4.4. Análises do teste de esforço máximo aeróbio ............................................. 36

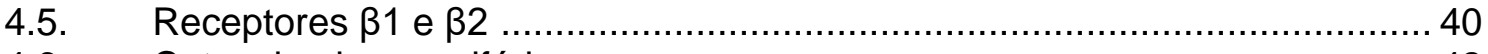

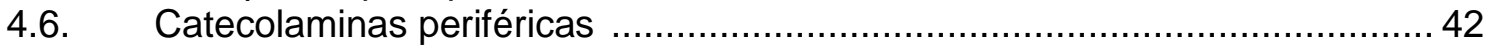

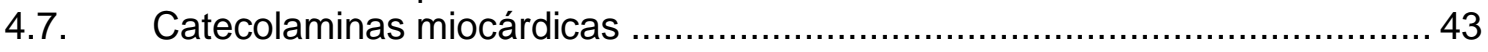

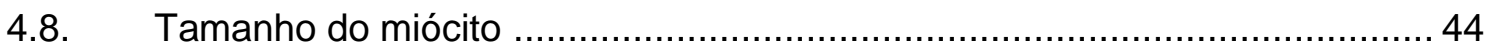

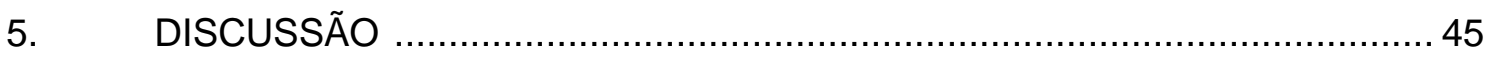

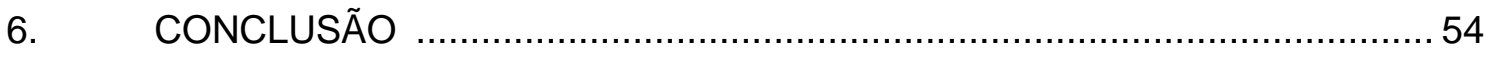

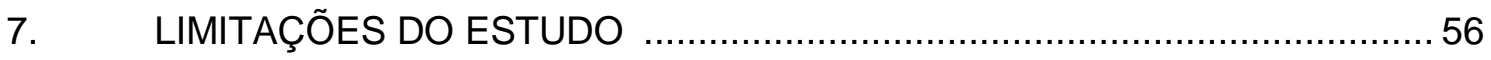

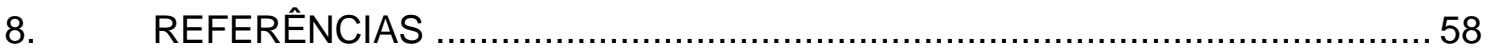




\section{LISTA DE ABREVIATURAS E SIGLAS}

$\begin{array}{ll}{ }^{\circ} \mathrm{C} & \text { grau Celsius } \\ \mu \mathrm{g} & \text { micrograma } \\ \mu \mathrm{L} & \text { microlitro } \\ \mu \mathrm{m} & \text { micrômetro } \\ \mathrm{AF} & \text { alta frequência } \\ \mathrm{BF} & \text { baixa frequência } \\ \mathrm{BIL} & \text { simpatectomia bilateral } \\ \text { cDNA } & \text { ácido desoxirribonucleico complementar } \\ \text { CEUA } & \text { Comitê de ética para uso animal } \\ \text { COBEA } & \text { Colégio Brasileiro de Estudos com Animais } \\ \text { CT } & \text { controle } \\ \text { CTA } & \text { controle com atenolol } \\ \text { DC } & \text { débito cardíaco } \\ \text { DCT } & \text { transformada discreta de cosseno } \\ \text { DD } & \text { diâmetro diastólico final do ventrículo esquerdo } \\ \text { DEPC } & \text { pirocarbonato de dietila } \\ \text { DHBA } & \text { dihidroxibenzilamina } \\ \text { DNase } & \text { desoxiribonuclease } \\ \text { DP IP } & \text { desvio padrão do intervalo de pulso } \\ \text { DS } & \text { diâmetro sistólico final do ventrículo esquerdo } \\ \text { DSR } & \text { denervação simpática renal } \\ \text { EME } & \text { estimulação da medula espinhal } \\ \text { FAPESP } & \text { Fundação de Amparo à Pesquisa do Estado de São Paulo } \\ \text { FC } & \text { frequência cardíaca } \\ \text { FMUSP } & \text { Faculdade de Medicina da Universidade de São Paulo } \\ \text { FE } & \text { fração de ejeção } \\ \text { FiO } & \text { fração inspirada de oxigênio } \\ \text { GAPDH } & \text { gliceraldeído-3-fosfato desidrogenase } \\ \text { HE } & \text { hematoxilina-eosina } \\ \text { HPLC } & \text { cromatografia líquida de alta performance } \\ \text { IC } & \text { insuficiência cardíaca } \\ \text { IP } & \text { intervalo de pulso } \\ & \end{array}$




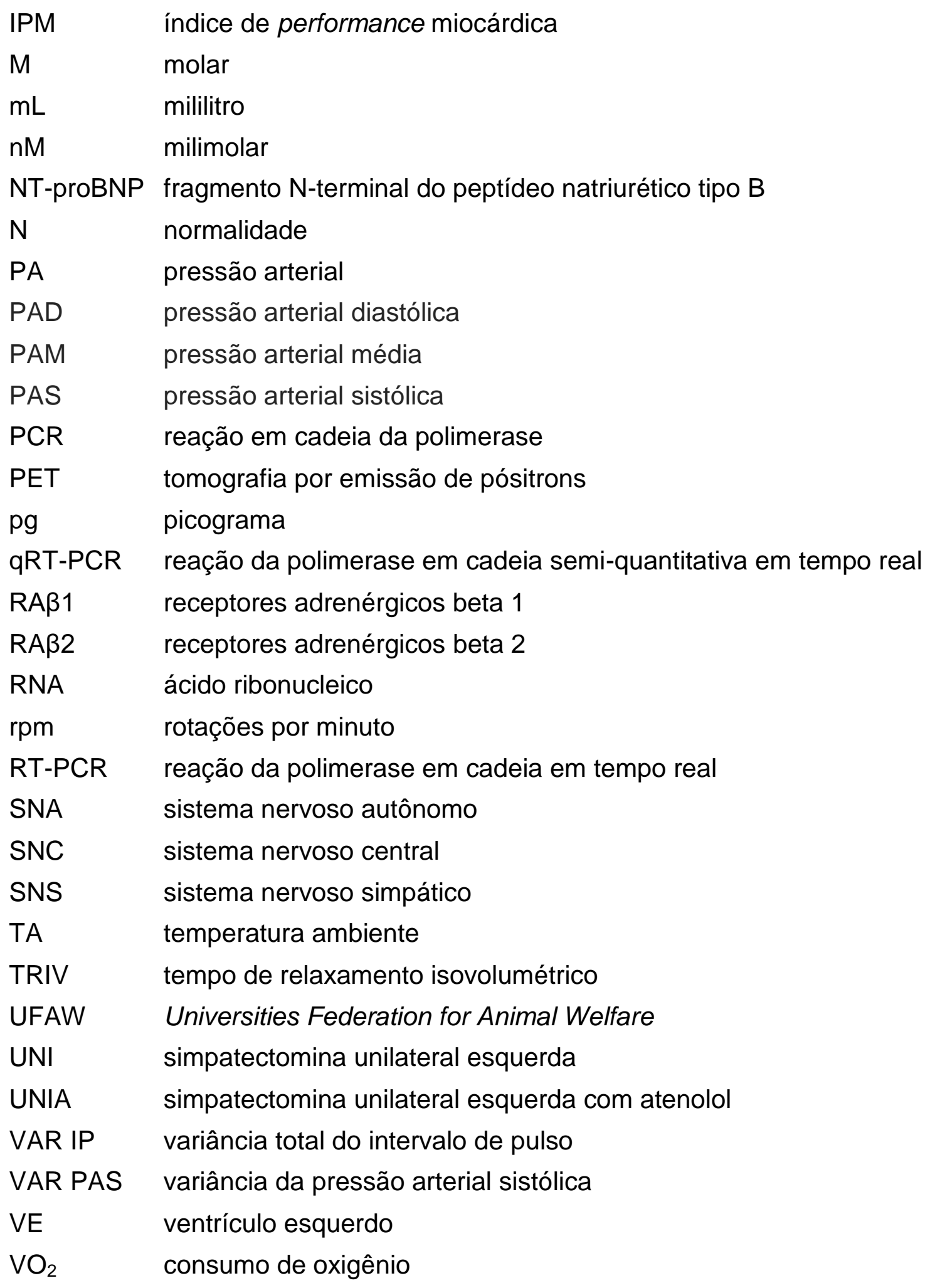




\section{LISTA DE FIGURAS E TABELAS}

Figura 1 - Animal após procedimento de simpatectomia .................................... 15

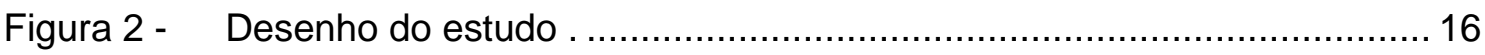

Figura 3 - $\quad$ Corte em HE do miócito ilustrando sua medida ................................. 28

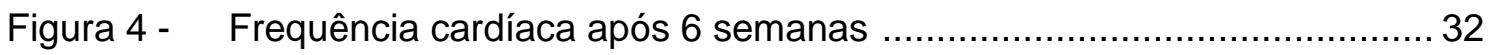

Figura 5 - Diâmetro sistólico e diastólico final do ventrículo esquerdo .....................33

Figura 6 - Fração de ejeção do ventrículo esquerdo ........................................ 34

Figura 7 - Variável alta frequência da análise de modulação autonômica................ 35

Figura 8 - Pressão arterial sistólica e diastólica em repouso .................................... 37

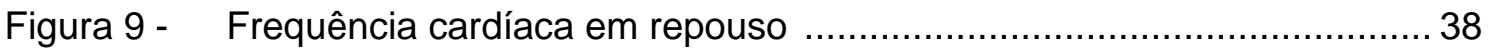

Figura 10 - Pressão arterial diastólica e média no pico do esforço .......................... 39

Figura 11 - Frequência cardíaca no pico do esforço ............................................ 40

Figura 12 - Receptores $\beta 1$ no ápice e na base do VE ….................................... 41

Figura 13 - Receptores $\beta 2$ no ápice e na base do VE ......................................... 41

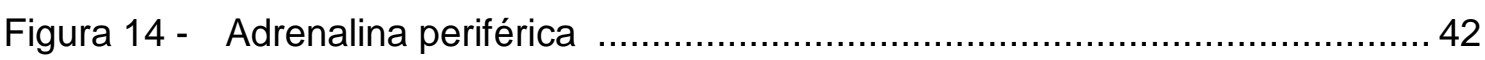

Figura 15 - Noradrenalina periférica ….............................................................. 43

Tabela 1 - Primers usados para avaliar os receptores $\beta$-adrenérgicos .................... 24

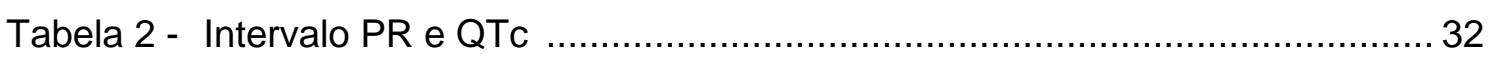

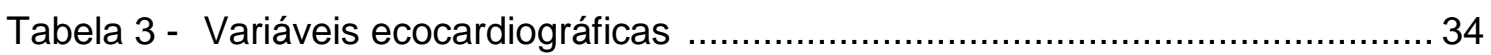

Tabela 4 - Variáveis da modulação autonômica …….............................................. 35

Tabela 5 - Variáveis do teste de esforço máximo aeróbio ....................................... 36

Tabela 6 - Concentração miocárdica de catecolaminas ....................................... 43

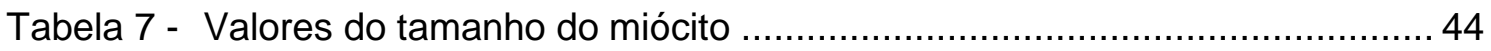




\section{RESUMO}

Jordão MR. Efeitos da simpatectomia no miocárdio [tese]. São Paulo: Faculdade de Medicina, Universidade de São Paulo; 2017.

A simpatectomia é uma modalidade terapêutica ampla e consagrada há décadas para determinadas patologias. Recentemente, alguns trabalhos sugerem a aplicação de tal técnica no tratamento da insuficiência cardíaca. Contudo, seus efeitos fisiológicos cardíacos em modelos experimentais foram pouco estudados. O objetivo deste trabalho é avaliar os efeitos fisiológicos da simpatectomia no coração. Para tal, foi utilizado o modelo experimental de simpatectomia em ratos pela técnica de esclerose do gânglio estrelado por punção e injeção de álcool absoluto. O estudo avaliou cinco grupos: controle (15 animais), simpatectomia unilateral esquerda (15 animais), simpatectomia bilateral (31 animais), simpatectomia unilateral esquerda com atenolol (15 animais) e atenolol sem simpatectomia (15 animais). Foram avaliadas as variáveis relacionadas ao sistema nervoso autônomo, como propriedades cronotrópicas em repouso e ao esforço, modulação autonômica cardiovascular, catecolaminas miocárdicas e periféricas e receptores beta-adrenérgicos do miocárdio. Também foram analisados os efeitos na função ventricular e no tamanho do miócito. As variáveis propostas para análise foram obtidas por ECG de repouso, ecocardiograma, teste de esforço máximo, frequência cardíaca ao esforço e variabilidade da FC e da PAS avaliadas no domínio do tempo e da frequência. As informações do miocárdio quanto a receptores, catecolaminas miocárdicas, catecolaminas periféricas e tamanho dos miócitos foram obtidas por PCR, ELISA, HPLC e morfometria do miócito, respectivamente. Este estudo evidenciou que os animais do grupo bilateral apresentam maiores níveis de catecolaminas periféricas e, consequentemente, são mais taquicárdicos e hipertensos. Os achados sugerem a ativação, neste grupo, de uma via compensatória que pode ter efeitos deletérios.

Descritores: simpatectomia, sistema nervoso autônomo, miocárdio 


\begin{abstract}
Jordão MR. Sympathectomy effects upon myocardium [thesis]. São Paulo: "Faculdade de Medicina, Universidade de São Paulo"; 2017.

Sympathectomy is a therapeutic modality used to treat certain diseases during decades. Recently, some studies suggest the application of this technique in the treatment of heart failure. However, its physiological effects upon the heart have been slightly studied. The objective of this study was to evaluate the physiological effects of sympathectomy in the heart. For this purpose, we used the experimental model of sympathectomy in rats by stellate ganglion sclerosis technique starring puncture and absolute alcohol injection. The study evaluated five groups of wistar rats: control (15), left unilateral sympathectomy (15), bilateral sympathectomy (31), left unilateral sympathectomy with atenolol (15) and atenolol without sympathectomy (15). We assessed variables related to the autonomic nervous system, such as chronotropic properties at rest and stress, cardiovascular autonomic modulation, myocardial and peripheral catecholamines and beta-adrenergic receptors in the myocardium. As well, we studied the effects on ventricular function and myocyte size. The proposed variables for analysis were obtained by resting electrocardiogram, echocardiography, maximal exercise test, heart rate at exercise and heart rate and systolic blood pressure variability in the time and frequency domain. The myocardial receptors, myocardial and peripheral catecholamines and myocyte size were obtained by PCR, ELISA, HPLC and myocyte morphometry, respectively. This study showed that the animals in the bilateral group had higher levels of peripheral catecholamine and, consequently, a higher heart rate and blood pressure. These findings suggest the activation of a compensatory pathway in the sympathectomy group that may have deleterious effects.
\end{abstract}

Descriptors: sympathectomy, autonomic nervous system, myocardium remodeling 
1. INTRODUÇÃO 
Uma das primeiras descrições do sistema nervoso autônomo (SNA) foi feita por Langley no início do século passado, quando o definiu como fibras nervosas que saíam do sistema nervoso central para os vasos sanguíneos e vísceras, divididas em sistema simpático (toracolombar) e parassimpático (craniosacral). Esta separação baseou-se no desenvolvimento embrionário, na distribuição da inervação para os órgãos-alvo e seus efeitos antagônicos em resposta a estímulos elétricos e a fármacos como adrenalina, pilocarpina ou atropina. Os segmentos espinhais de feixes nervosos para diferentes órgãos foram definidos examinando a resposta orgânica a diferentes estímulos da raiz ventral. Além disso, sinapses ganglionares foram localizadas por aplicação tópica de nicotina. Este estudo indicou que os órgãos recebem inervação simpática e parassimpática e que seus efeitos geralmente se opõem ${ }^{1}$. Pouco tempo depois, Walter Cannon ${ }^{2}$ descreveu o sistema nervoso simpático (SNS) como o centro regulador da homeostase, mostrando que animais com estímulos agressores (estressores) respondiam com ativação do SNS, o que implicava em alterações no suprimento sanguíneo, disponibilidade de açúcar, alterações na formação do coágulo, mobilizando recursos para um intenso gasto energético, direcionado a uma resposta de emergência de luta ou fuga.

O SNS tem ampla variedade de ações no sistema cardiovascular, incluindo elevação da frequência cardíaca (FC), aumento da contratilidade miocárdica, redução da capacitância venosa e aumento da resistência vascular. As fibras nervosas simpáticas cardíacas estão localizadas no epicárdio, seguindo o trajeto das artérias coronárias e representam o principal componente autonômico dos ventrículos. As fibras parassimpáticas 
acompanham o nervo vago no subendocárdio e, após cruzar o sulco atrioventricular, distribuem-se predominantemente no miocárdio atrial ${ }^{3}$. A inervação simpática ventricular é caracterizada por gradiente da base para o ápice ${ }^{4}$, com maior densidade de fibras na base, diminuindo para o ápice de maneira oposta aos receptores $\beta$ que invertem esta distribuição ${ }^{5}$. O fluxo simpático para o coração e periferia é regulado por reflexos cardiovasculares. Fibras aferentes levam o impulso ao sistema nervoso central (SNC) por nervos autonômicos, enquanto impulsos eferentes saem do SNC para diferentes órgãos, tanto por nervos autonômicos, como somáticos. As principais respostas reflexas originam-se do arco aórtico e barorreceptores carotídeos (inibição do SNS), barorreceptores cardiopulmonares (diversos reflexos incluindo o reflexo de Bezold-Jarisch, inibição do SNS), receptores cardiovasculares polimodais de baixo limiar (ativação do SNS) e quimiorreceptores periféricos (ativação do SNS).

O efeito da ativação do SNS na periferia é mediado por quatro vias: 1) noradrenalina liberada pelo gânglio estrelado direito que atua no nó sinusal e atrioventricular, resultando em aumento da freqüência cardíaca e diminuição da condução atrioventricular, e a noradrenalina liberada pelo gânglio estrelado esquerdo, atuando no ventrículo esquerdo, com aumento de força de contração miocárdica e pressão arterial; 2) adrenalina liberada pelo córtex adrenal que atua no miocárdio e vasos periféricos; 3) efeito direto nos vasos periféricos pela liberação local de adrenalina e noradrenalina; 4) noradrenalina circulante com múltiplos locais de ação.

Os neurotransmissores (noradrenalina e adrenalina) ligam-se a receptores adrenérgicos específicos presentes na membrana celular para 
exercer seus efeitos biológicos. Existem nove subtipos diferentes de receptores adrenérgicos: três $\alpha 1$-receptores ( $\alpha 1 \mathrm{~A}, \alpha 1 \mathrm{~B}$ e $\alpha 1 \mathrm{D})$, três $\alpha 2$-receptores $(\alpha 2 \mathrm{~A}, \alpha 2 \mathrm{~B}$ e $\alpha 2 C$ ) e três $\beta$-receptores $(\beta 1, \beta 2 \text { e } \beta 3)^{6}$. O miocárdio humano apresenta os três subtipos de receptores adrenérgicos $\beta$. Os subtipos $\beta 1$ e $\beta 2$ estão presentes na proporção de 7:3 e, quando estimulados, aumentam a contratilidade cardíaca (efeito inotrópico positivo), a frequência cardíaca (efeito cronotrópico positivo), a capacidade de relaxamento do miocárdio (efeito lusitrópico positivo), como também a condução de impulsos através do nó atrioventricular (efeito dromotrópico positivo). Os receptores adrenérgicos $\beta 3$ estão predominantemente inativos em condições fisiológicas. Entretanto, sua estimulação parece produzir efeito inotrópico negativo, antagônico ao estímulo induzido por receptores adrenérgicos $\beta 1$ e $\beta 2$ que envolve a via da enzima óxido nítrico sintase e age como válvula de segurança durante, estimulação adrenérgica intensa. ${ }^{7}$

No miocárdio humano, a ativação dos receptores adrenérgicos $\beta 1$ e $\beta 2$ é o mecanismo fisiológico mais eficaz para aumentar rapidamente o débito cardíaco. Receptores adrenérgicos $\beta 1$ ativam exclusivamente proteínas Gs que potencializam a ação nos receptores adrenérgicos, enquanto os receptores adrenérgicos $\beta 2$ usam as proteínas Gs e também as Gi que minimizam a ação nos receptores adrenérgicos. ${ }^{8}$

O miocárdio humano também expressa receptores adrenérgicos $\alpha 1 \mathrm{~A} \mathrm{e}$ $\alpha 1 \mathrm{~B}$ em proporções menores (20\%) que os receptores adrenérgicos $\beta,{ }^{9}$ com papel desconhecido em situações fisiológicas. Além disso, os receptores adrenérgicos $\alpha 1$ são muito numerosos em artérias maiores (aorta, artéria 
pulmonar, vasos mesentéricos e coronárias) e, quando ativados pela noradrenalina e adrenalina, são os maiores responsáveis pela regulação do fluxo sanguíneo por vasoconstrição.

Nos últimos 20 anos, diversos estudos, clínicos e experimentais, demonstraram a participação do SNS em várias doenças cardiovasculares, como a hipertensão arterial sistêmica, insuficiência cardíaca congestiva, arritmias cardíacas, infarto do miocárdio e acidente vascular cerebral. ${ }^{10} \mathrm{~A}$ ativação do SNS também foi evidenciada em doenças metabólicas como o diabetes, a obesidade e a síndrome metabólica. ${ }^{11} \mathrm{Na}$ insuficiência renal crônica, há evidências que caracterizam maior atividade adrenérgica, o que eleva o perfil de risco cardiovascular nesta população. ${ }^{12}$ Isto posto, intervenções terapêuticas focadas na modulação desta hiperatividade simpática são de fundamental importância no controle e progressão destas doenças. O melhor exemplo desta afirmação é o uso de $\beta$-bloqueadores no tratamento da insuficiência cardíaca congestiva, desde o final dos anos 90, após os resultados dos estudos US-Carvedilol, ${ }^{13}$ CIBIS-II, ${ }^{14}$ MERIT-HF, ${ }^{15}$ COPERNICUS $^{16}$ e CAPRICORN ${ }^{17}$ demonstrando a redução significativa da morbidade e mortalidade nesta condição clinica.

Pela conhecida associação entre SNS e coração, e pelo potencial benefício de algumas modalidades terapêuticas que visam a esta interação, exemplificada pelos resultados alcançados com alguns dos $\beta$-bloqueadores, ações intervencionistas no SNS passaram a ser estudadas nas doenças cardiovasculares. ${ }^{18,19}$ Dentre as modalidades terapêuticas, com esta proposta, destacam-se: sensibilização baroreflexa, estimulação vagal, estimulação da 
medula espinhal, denervação simpática renal (DSR) e denervação simpática cardíaca (simpatectomia).

A sensibilização, ou terapia de ativação barorreflexa, é feita por estimulação elétrica dos barorreceptores da carótida e é baseada na ativação da via aferente deste reflexo, induzindo o sistema nervoso central a reequilibrar a modulação autonômica do sistema cardiovascular. Os dispositivos funcionam como um marcapasso e provocam estímulo elétrico nos seios carotídeos através de eletrodos. Resultados em modelos animais com insuficiência cardíaca (IC) demonstraram aumento da sobrevida e benefício no remodelamento cardíaco, o que viabilizou estudos clínicos em IC com fração de ejeção (FE) reduzida. ${ }^{20}$ Os resultados em pacientes com hipertensão arterial sistêmica refratária sugerem, ainda, potencial benefício para pacientes com IC e FE preservada. ${ }^{21}$ Zile et al. $^{22}$ compararam os efeitos desta terapia em pacientes classe funcional III com FE $<35 \%$, com e sem terapia de ressincronização cardíaca, e evidenciaram benefício na qualidade de vida, teste de caminhada de 6 minutos, FE, níveis de NT-proBNP e re-hospitalização nos pacientes sem ressincronização cardíaca. O estudo BeAT-HF (Barostim Therapy for Heart Failure) está em andamento e pretende avaliar estes potenciais benefícios, exclusivamente em pacientes sem ressincronização cardíaca.

A estimulação vagal segue um racional parecido com a terapia de ativação barorreflexa, através de estímulos elétricos diretamente no nervo vago, tentando corrigir o desequilíbrio autonômico com o aumento do tônus parassimpático vagal. A estimulação vagal ativa fibras aferentes que causam diminuição reflexa da atividade simpática eferente. Além disso, modelos 
experimentais demonstraram diminuição da ativação do sistema reninaangiotensina. A estimulação vagal cervical também promove liberação de óxido nítrico no coração e benefícios no reflexo inflamatório. ${ }^{23}$ Resultados clínicos e experimentais serviram de base para estudos maiores comprovarem a eficácia desta terapia. O estudo NECTAR-HF (NEural Cardiac TherApy foR Heart Failure) ${ }^{24}$ foi o primeiro ensaio randomizado, controlado, desenhado para avaliar a segurança e eficácia da estimulação nervosa vagal do lado direito em pacientes com IC e disfunção sistólica. Entretanto, esse estudo não mostrou diferença significativa entre os grupos. O estudo ANTHEM-HF (Autonomic Neural Regulation Therapy to Enhance Myocardial Function in Heart Failure ${ }^{25}$ foi outro estudo com pacientes portadores de IC crônica e disfunção sistólica randomizados para estimulação vagal cervical esquerda ou direita. O estudo mostrou melhora da fração de ejeção ventricular esquerda, sem diferenças entre lado esquerdo e direito. Houve, também, melhora no teste de caminhada de 6 minutos, mais evidente no estimulo à direita, e melhora na qualidade de vida sem diferença entre os lados. O estudo INOVATE-HF (INcrease Of VAgal TonE in Heart Failure $)^{26}$ avaliou 707 pacientes com IC e disfunção sistólica (classe funcional III e FE <40\%) e não mostrou benefício da estimulação do nervo vagal.

A estimulação da medula espinhal (EME), com dispositivos implantáveis, tem sido utilizada em todo o mundo, durante décadas, para tratamento de dores e angina refratária. Estudos pré-clínicos com estimulação da medula espinhal, em modelos experimentais de doença cardíaca, descreveram efeitos interessantes sobre a fisiologia do sistema nervoso 
autônomo cardíaco com reversão da dilatação do ventrículo esquerdo e melhora da função cardíaca, além de supressão de arritmias, servindo de base para estudos clínicos. ${ }^{27}$ O maior estudo é o Defeat-HF (Determining the Feasibility of Spinal Cord Neuromodulation for the Treatment of Chronic Heart Failure) ${ }^{28}$ ensaio clínico para determinar a segurança e eficácia da EME em pacientes com insuficiência cardíaca avançada. Este estudo não evidenciou benefício.

A denervação simpática renal (DSR) foi considerada no cenário de IC e abordada por alguns estudos. O estudo-piloto OLOMOUC $1^{29}$ comparou os efeitos da DSR ao tratamento farmacológico otimizado em 51 pacientes com IC avançada. Os autores demonstraram que a DSR é segura, não altera a função renal, melhora a função sistólica do ventrículo esquerdo e reduz a FC média. A DSR ainda reduziu os volumes ventriculares esquerdos e NT-proBNP. Apesar dos resultados promissores, esse estudo foi unicêntrico, sem randomização e nem todos os pacientes tiveram tratamento médico otimizado. O estudo REACH (Renal Artery Denervation in Chronic Heart Failure) ${ }^{30}$ teve como objetivo avaliar os efeitos da DSR em pacientes com IC sistólica e não demonstrou alterações nas variáveis ecocardiográficas, sugerindo apenas benefício em sintomas. Nesse mesmo contexto, em andamento, o Symplicity- $\mathrm{CHF}^{31}$ avaliará a segurança e a eficácia da DSR em pacientes com classe funcional II a III e $\mathrm{FE}<40 \%$.

Além dos dispositivos e intervenções percutâneas no SNS, outra modalidade terapêutica com este mesmo propósito é a intervenção cirúrgica. Esta foi descrita desde 1880 para o tratamento da espasticidade, epilepsia, 
angina, bócio e hipertensão. Contudo, perdeu impacto na prática clínica após Leriche $^{32}$ publicar, em 1932, grave complicação pela infusão de álcool no espaço subaracnoideo torácico, através da bainha nervosa. A partir da década de 30 , foram desenvolvidas novas técnicas de simpatectomia aberta em nível esplênico, lombar e torácico para o tratamento de dor, hiperhidrose, vasculopatias e cardiopatias. Nos anos 80 , introduziu-se a simpatectomia percutânea por radiofrequência, em nível torácico e lombar e, no começo da década de 90, adotou-se a tecnologia por vídeo, chamada de simpatectomia toracoscópica assistida por vídeo. Posteriormente, estas técnicas endoscópicas refinaram-se com incisões mínimas. Atualmente, são indicadas em casos de hiperhidrose focal patológica, disautonomia dolorosa, em algumas vasculopatias como Raynaud, doença de Buerger e macroglobulinemia, além de cardiopatias como a síndrome do QT longo congênito, casos selecionados de doença arterial coronariana e arritmias. Recentemente, foi testada a simpatectomia por clipagem do terço inferior do gânglio estrelado esquerdo e dos nervos torácicos T3-T4 por videotoracoscopia em dez pacientes com IC classes II e III, comparados com cinco pacientes do grupo controle submetidos a tratamento clínico. Os resultados sugerem diferença entre os dois grupos quanto à melhora da classe funcional. Embora não tenha havido diferença no pico de $\mathrm{VO}_{2}$, nos níveis de BNP e na atividade simpática muscular, os pacientes do grupo intervenção mostraram melhora estatisticamente significativa no teste de caminhada de 6 minutos e no questionário de qualidade de vida. Este estudo levantou questionamentos e possibilidades interessantes. $^{33}$ 
Contudo, apesar das variadas indicações da simpatectomia por diferentes técnicas, seus efeitos fisiológicos no miocárdio foram pouco estudados. Modelos experimentais não patológicos em denervação simpática miocárdica são escassos. ${ }^{34,35}$ Yoshimoto et al. ${ }^{34}$ estudaram ratos denervados por gangliectomia bilateral do núcleo estrelado com dois propósitos. Primeiramente, validar a metodologia e o modelo experimental, o que foi atingido, demonstrado pela dosagem de noradrenalina que estava significativamente mais baixa em todas as câmaras cardíacas comparadas com o grupo sham. O segundo objetivo foi comparar a resposta ao atenolol do grupo controle com os denervados. Os resultados sugeriram que o efeito hipotensor do fármaco não é mediado pelo bloqueio do receptor adrenérgico beta-1 miocárdico. ${ }^{34}$ Mais recentemente, Jiang et al. ${ }^{35}$ avaliaram os efeitos da simpatectomia química com 6-hidroxidopamina na variabilidade da FC, parâmetros de ECG, ecocardiograma e alterações histológicas em ratos sadios. Outros efeitos da simpatectomia no miocárdio não foram investigados em modelos experimentais e têm dados extrapolados da experiência clínica que, muitas vezes, são controversos. Portanto, face ao andamento dos estudos clínicos, consideramos fundamental a obtenção de dados da fisiologia do coração, no cenário da simpatectomia. 
2. OBJETIVOS 


\subsection{Objetivo geral}

O objetivo deste trabalho é avaliar os efeitos fisiológicos da simpatectomia no miocárdio em modelo experimental.

\subsection{Objetivos específicos}

Avaliar a repercussão da simpatectomia unilateral esquerda e bilateral nos receptores beta do miocárdio, catecolaminas miocárdicas e periféricas, alterações estruturais e funcionais no miocárdio, além da avaliação da função autonômica. 
3. MATERIAIS E MÉTODOS 


\subsection{Modelo experimental}

Foram utilizados 91 ratos machos Wistar, com idade de oito semanas, adquiridos do Biotério Central da Faculdade de Medicina da Universidade de São Paulo (FMUSP). Esses animais foram mantidos em gaiolas apropriadas com três animais em cada uma, com ração e água ad libitum e identificados com chip subcutâneo. O protocolo seguiu as normas de cuidados em experimento animal definidas pelo COBEA (Colégio Brasileiro de Estudos com Animais) ${ }^{36}$ e UFAW (Universities Federation for Animal Welfare), ${ }^{37}$ teve aprovação do Comitê de Ética para Uso Animal (CEUA, 225/12) da FMUSP e obteve suporte financeiro da Fundação de Amparo à Pesquisa do Estado de São Paulo (FAPESP - Processo 2012/02772-8).

Os animais foram divididos em cinco grupos:

1. Controle (CT) - 15 animais

2. Controle com atenolol (CTAT) - 15 animais

3. Simpatectomia unilateral esquerda (UNI) - 15 animais

4. Simpatectomina unilateral esquerda com atenolol (UNIA) - 15 animais

5. Simpatectomia bilateral (BIL) - 31 animais

A simpatectomia foi realizada por meio de ablação química do gânglio estrelado. Após anestesia geral com isoflurano (3,0\% para indução e 1,5\% para manutenção) em oxigênio $\left(\mathrm{FiO}_{2} 100 \%\right)$, os ratos foram colocados em decúbito ventral. $O$ acesso ao gânglio estrelado (esquerdo ou bilateral) foi feito pela técnica percutânea posterior ${ }^{38}$ e a gangliectomia química induzida por injeção 
periganglionar de álcool absoluto. Após a palpação do processo espinhoso da vértebra C7, localizado entre as duas escápulas, foi inserida uma agulha de pequeno calibre (25G) acoplada a uma seringa de $1,0 \mathrm{~mL}$ no plano sagital paramediano, avançando-a na direção póstero-anterior do processo espinhoso da C7. Quando a ponta da agulha perdeu o contato com o corpo vertebral (sinal que passou a face anterior do corpo vertebral), foi retraída $0,5 \mathrm{~mm}$ e injetado 0,2 mL de álcool absoluto. A confirmação clínica da ablação química do gânglio estrelado foi feita pela observação de ptose palpebral ipsilateral e irreversível (síndrome de Horner), após recuperação anestésica (figura 1). Os grupos com atenolol (CTAT e UNIA) receberam a dose de $90 \mathrm{mg} / \mathrm{kg} / \mathrm{dia}$, administrado por gavage uma vez ao dia. ${ }^{39}$

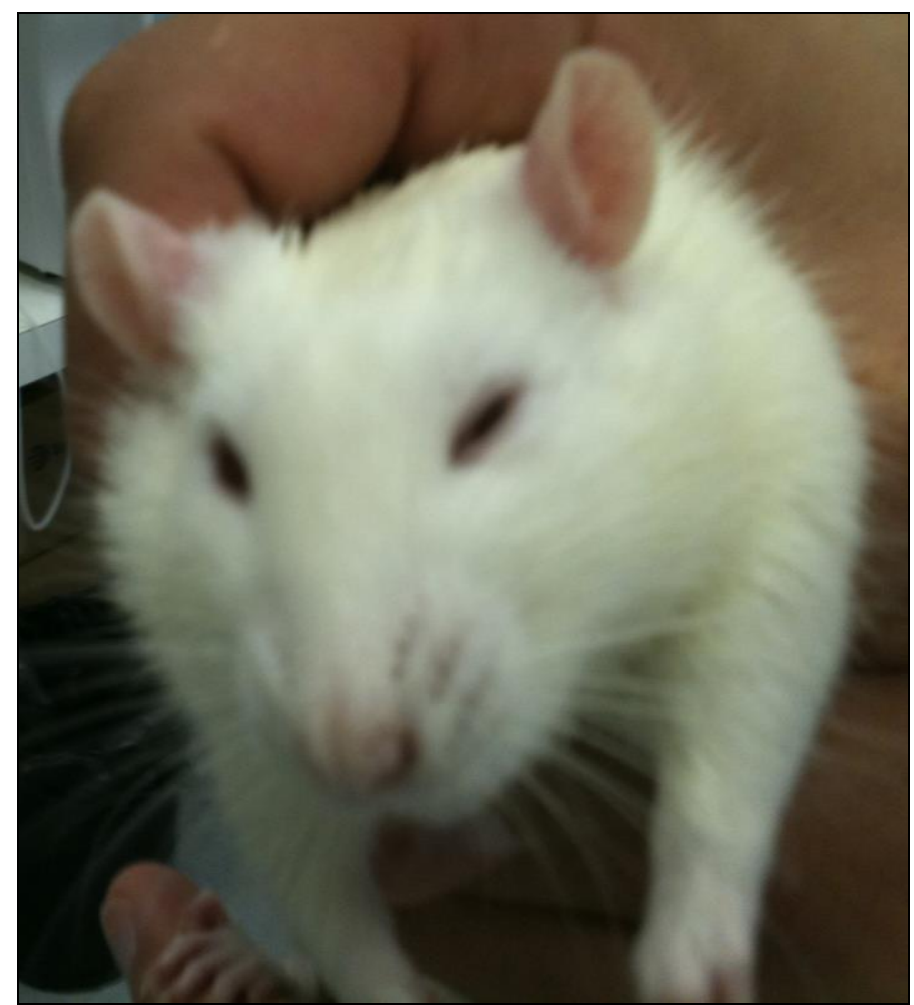

Figura 1 - Animal após procedimento de simpatectomia por esclerose do gânglio estrelado esquerdo confirmado por ptose palpebral à esquerda 
No grupo BIL, devido à mortalidade elevada (77\%), os animais que morreram no procedimento, ou até quatro horas após, foram repostos.

Cada grupo teve uma avaliação eletrocardiográfica, ecocardiográfica, resposta cardiovascular ao esforço e modulação autonômica com seis semanas. Logo após, foi realizada a eutanásia e coletado material para o estudo dos receptores beta do miocárdio (ápice e base do ventrículo esquerdo), tamanho do miócito e catecolaminas miocárdicas e periféricas (figura 2).

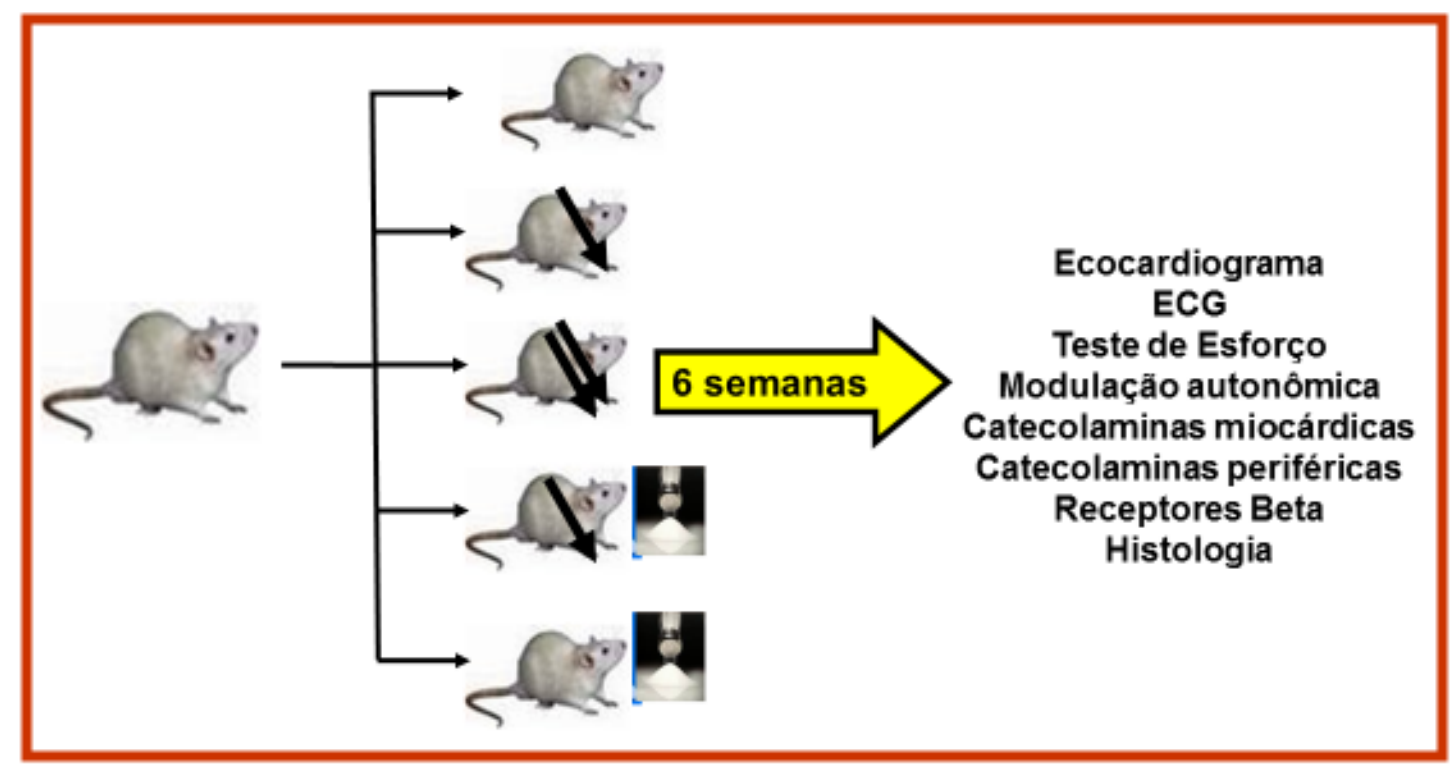

Figura 2 - Desenho do estudo

Os animais sofreram eutanásia sob anestesia com ketamina $50 \mathrm{mg} / \mathrm{kg}$ e xylazina $10 \mathrm{mg} / \mathrm{kg}$. Foi realizada laparotomia mediana, com dissecção e punção da veia cava e administração de solução com cloreto de potássio (soro fisiológico 0,9\% $80 \mathrm{~mL}+\mathrm{KCl} 19,1 \% 20 \mathrm{~mL}$ ), até a parada cardíaca. Após a eutanásia, cada animal foi colocado em saco leitoso com identificação da espécie, data e procedência do laboratório e entregue para o descarte, que foi 
realizado conforme as normas de descarte de material biológico do Biotério do Instituto do Coração do Hospital das Clínicas da FMUSP.

\section{$3.2 \quad$ Eletrocardiograma}

A avaliação eletrocardiográfica constou da aferição da FC, tempo de condução atrioventricular (intervalo PR), duração do intervalo QT corrigido (fórmula Frederica) e ritmo.

O eletrocardiograma foi realizado no aparelho Dixtal - Eletropagina (eletrocardiógrafo três canais EP-3), conectando-se os eletrodos nas patas dianteiras e traseiras dos animais, respeitando as referências: braço direito, braço esquerdo, perna esquerda e perna direita. Foram realizadas as derivações DI, DII, DIII, aVR, aVL e avF, em ganho de $2 \mathrm{~N}$ e velocidade 50

mm/s. O papel usado foi o ECG Recording Paper Series 4700AH da Hewlett Packard. Os animais foram submetidos a este exame anestesiados com uma combinação de ketamina $(50 \mathrm{mg} / \mathrm{kg})$ e xylazina $(10 \mathrm{mg} / \mathrm{kg})$ via intraperitoneal.

\subsection{Ecocardiograma}

Após o ECG, foi realizado o ecocardiograma transtorácico modo M, bidimensional e Doppler pulsado, utilizando-se o aparelho Acuson, modelo Sequóia 512, com transdutor de $9 \mathrm{~mm}$ e frequência de $13 \mathrm{mHz}$. O padrão de contração regional e global foi avaliado, em tempo real, nos cortes paraesternal longitudinal e transverso do ventrículo esquerdo (VE). As dimensões cardíacas 
sistólicas e diastólicas foram analisadas pelo modo M. A função ventricular sistólica foi calculada utilizando-se a medida da fração de ejeção (FE) pelo método do cubo. Tempo de relaxamento isovolumétrico (TRIV) foi avaliado para a análise da função diastólica, pelo Doppler pulsado, na medida do fluxo de via de entrada do VE. O índice de performance miocárdica (IPM) foi analisado pela fórmula: (a - tempo de ejeção) / tempo de ejeção, sendo "a" o intervalo entre o fechamento e a abertura da valva mitral. Esse índice foi usado para avaliação da função global do coração. Os animais foram submetidos a este exame sob efeito da mesma anestesia utilizada para realização do ECG. O exame foi realizado de acordo com a sua padronização em ratos, sendo considerados como valores normais os ecocardiogramas dos animais do grupo controle.

\subsection{Avaliação da modulação autonômica cardiovascular}

A variabilidade da FC e da pressão arterial sistólica (PAS) foi avaliada no domínio do tempo (variância) e no domínio da frequência, utilizando a transformada rápida de Fourier. Para obter a mensuração dos registros, foi inserido um cateter na artéria carótida direita, sob anestesia inalatória, com o uso de máscara de inalação, com a mistura de 3 litros de oxigênio e $2 \%$ de isoflurano. O animal anestesiado foi colocado em decúbito dorsal e realizada uma incisão na região do pescoço e dissecada a artéria carótida, próximo da traqueia, para introdução do cateter $(2,5 \mathrm{~cm})$. Este procedimento foi realizado 24 horas antes da data do teste de esforço. 
A avaliação foi feita imediatamente antes do teste de esforço, sendo analisados cinco animais aleatoriamente nos grupos CT, CTAT, UNI, UNIA e sete animais no BIL. Neste método, séries temporais do intervalo de pulso (IP) e da PAS foram divididas em segmentos de 512 batimentos com sobreposição de $50 \%$. Um espectro foi obtido para cada um dos segmentos e os componentes oscilatórios dos espectros foram quantificados em duas faixas de frequência: baixa frequência (BF 0,20 a $0,75 \mathrm{~Hz}$ ), representando modulação simpática e alta frequência ( $\mathrm{AF} 0,75$ a $3 \mathrm{~Hz}$ ), modulação parassimpática. A potência do espectro foi calculada para cada componente reconhecível nas faixas de BF e AF, integrando-se os espectros dos componentes por meio do software Cardioseries 2.4. Os segmentos que apresentaram oscilações muito lentas $(<0,2 \mathrm{~Hz})$ foram considerados não estacionários e descartados do estudo. A sensibilidade barorreflexa espontânea foi obtida pelo índice $\alpha$, analisando a correlação temporal e linear entre o valor absoluto de BF para o IP e da PAS. ${ }^{40,41}$ Com isso, foram avaliadas as variáveis do IP, entre elas 0 desvio padrão (DP IP) e a variância do intervalo de pulso (VAR IP). Foi avaliada, também, a variância da pressão arterial sistólica (VAR PAS) e valores absolutos da BF e AF.

\subsection{Teste de esforço máximo aeróbio}

Foram analisadas FC e pressão arterial (PA) ao esforço, utilizando o teste de esforço máximo aeróbio, além da distância percorrida e o tempo de exercício. 
O teste de esforço consistiu em um protocolo escalonado com incrementos de velocidade de $0,3 \mathrm{~km} / \mathrm{h}$ a cada 3 minutos, até atingir a velocidade máxima suportada pelos animais. O critério utilizado para a determinação da exaustão do animal e interrupção do teste foi o momento em que o animal não foi mais capaz de correr mediante 0 incremento de velocidade da esteira. $^{42}$

Os animais foram submetidos a treinamento prévio para adaptação por dois dias. Um dia antes do teste de esforço, os animais tiveram a artéria carótida canulada por cateter, conforme descrito, para permitir a aferição da PA e FC imediatamente antes do teste e no pico do esforço.

\subsection{Análise da atividade simpática}

\subsubsection{Receptores $\beta 1$ e $\beta 2$ no miocárdio}

A expressão gênica dos receptores $\beta 1$ e $\beta 2$, no ápice e na base do coração, separadamente, foi realizada pela técnica da reação em cadeia da polimerase em tempo real (RT - PCR). Como controle endógeno da reação foi utilizado o gene gliceraldeído-3-fosfato desidrogenase (GAPDH) e beta-actina.

\subsubsection{Extração do ácido ribonucleico (RNA)}

Para extração do RNA das amostras de tecido do coração foram utilizados de 50-100 mg de tecido em 1,0 mL de TRIzo/ $^{\circledR}$ Reagent (Invitrogen ${ }^{T M}$ ). 
O material foi triturado no $T R I z O^{\circledR}$ Reagent, até sua completa homogeneização, e mantido em temperatura ambiente (TA) por 5 minutos, sendo dado seguimento ao protocolo descrito na bula do reagente. Após adicionar $0,2 \mathrm{~mL}$ de clorofórmio e agitar vigorosamente com as mãos, durante 15 segundos, a amostra foi colocada em incubação de 3 minutos em TA. Essa mistura foi centrifugada a $4^{\circ} \mathrm{C}$, a uma velocidade de $12.000 \times$ g, durante 15 minutos. $\mathrm{A}$ parte aquosa foi removida e transferida para outro tubo limpo e estéril. Acrescentou-se $0,5 \mathrm{~mL}$ de álcool isopropanol e foi mantida em incubação em TA por 10 minutos. Em seguida, centrifugou-se a 12.000 x g, por 10 minutos, a uma temperatura de $4^{\circ} \mathrm{C}$. O sobrenadante foi removido e descartado, ficando apenas o precipitado, para ser lavado com $1 \mathrm{~mL}$ de álcool etílico, agitando o tubo no vortex e centrifugando por 5 minutos, a uma velocidade de $7.500 \times \mathrm{g} \mathrm{a}$ $4^{\circ} \mathrm{C}$. O sobrenadante foi, então, descartado deixando secar o precipitado formado no fundo do tubo, sendo em seguida eluído com 30-50 $\mu \mathrm{L}$ de água tratada com pirocarbonato de dietila (DEPC). As concentrações das amostras foram determinadas por meio da leitura em espectrofotômetro no comprimento de onda de 260/280 nm, utilizando-se o aparelho nanodrop (Thermo Scientific). A qualidade das mesmas foi verificada por meio de corrida de eletroforese em gel de agarose. Uma alíquota com $3 \mu \mathrm{g}$ de RNA de cada amostra foi separada, para a realização do tratamento e transcrição reversa e o restante das amostras foi armazenado em freezer $-80^{\circ} \mathrm{C}$. 


\subsubsection{Tratamento do RNA total com a enzima DNase free}

O RNA foi submetido ao tratamento com a enzima Turbo DNA-Free ${ }^{\mathrm{TM}}$ da empresa Ambion (The RNA Company). O protocolo do fabricante foi seguido rigorosamente, utilizando-se a quantidade de $3 \mu \mathrm{g}$ de RNA. Ao RNA, foram adicionados 1,2 $\mu \mathrm{L}$ de Turbo DNase Buffer 10X e 1,0 $\mu \mathrm{L}$ de Turbo DNase. As amostras foram, então, homogeneizadas vigorosamente e incubadas a $37^{\circ} \mathrm{C}$, durante 30 minutos, no equipamento Thermomixer Comfort (marca Eppendorf). Ao final da incubação, foi adicionado $1,2 \mu \mathrm{L}$ do reagente de inativação da DNase, seguido de incubação por 5 minutos, em TA (25ํ), também no Thermomixer Comfort (marca Eppendorf). Após o término da incubação, seguiuse a centrifugação da amostra a $10.000 \times \mathrm{g}$ por 1,5 minuto e o sobrenadante foi transferido para um novo tubo livre de RNase.

\subsubsection{Transcrição reversa (síntese de DNA complementar (cDNA))}

Para transcrição reversa, foi utilizada a enzima SuperScript ${ }^{T M}$ ॥ Reverse Transcriptase (Invitrogen ${ }^{T M}$ ). Foram utilizadas duas misturas: Mix 1 contendo $10 \mu \mathrm{L}$ de $R N A$ tratado $(3,0 \mu \mathrm{g}) ; 0,5 \mu \mathrm{L}$ de Oligo-(dT)12-18 Primer (Invitrogen $\left.^{T M}\right)(0,5 \mu \mathrm{g} / \mu \mathrm{L}) ; 0,5 \mu \mathrm{L}$ de random primers (Invitrogen $\left.{ }^{T M}\right)(3,0 \mu \mathrm{g} / \mu \mathrm{L}) \mathrm{e}$ 1,0 $\mu \mathrm{L}$ de dNTP (Invitrogen ${ }^{T M}$ ) (10 mM); e Mix 2 contendo 4,0 $\mu \mathrm{L}$ de tampão da enzima (5X); 2,0 $\mu \mathrm{L}$ de DTT $(0,1 \mathrm{M}) ; 1,0 \mu \mathrm{L}$ de RNase Out ${ }^{\mathrm{TM}}$ (Recombinant Ribonuclease Inhibitor-Invitrogen $\left.{ }^{T M}\right)$ 1,0 $\mu \mathrm{L}$ de SuperScript II. 
O Mix 1 (12 $\mu \mathrm{L}$ de volume) foi levado ao termociclador, à temperatura de $65^{\circ} \mathrm{C}$, por 5 minutos. O programa foi pausado e, então, o Mix $2(8,0 \mu \mathrm{L}$ por amostra) foi acrescentado. O programa foi continuado com as seguintes ciclagens: $42^{\circ} \mathrm{C}$ por 2 minutos, $42^{\circ} \mathrm{C}$ por 50 minutos, $70^{\circ} \mathrm{C}$ por 15 minutos e mantido a $4^{\circ} \mathrm{C}$ por tempo indeterminado, até ser retirado da máquina.

Os cDNAs foram posteriormente armazenados, à temperatura de $-20^{\circ} \mathrm{C}$.

\subsubsection{Reação de RT-PCR}

As reações de PCR em tempo real (RT-PCR) foram feitas em placas de 96 poços, usando reagente Power SYBR Green Master Mix (Applied Biosystems - EUA), conforme descrito pelo fabricante e o equipamento utilizado foi o Step One Plus Real-Time PCR Systems (Applied Biosystems).

A reação foi preparada com 10,0 $\mu \mathrm{L}$ de Sybr Green; 5,0 $\mu \mathrm{L}$ de cDNA diluído 1:40 e 5,0 $\mu \mathrm{L}$ de primer (forward e reverse) já diluídos na concentração determinada previamente, na reação de otimização dos primers, necessária para uma eficiência de 100\%. Essas quantidades foram utilizadas para elaboração da reação de qRT-PCR em duplicata. O programa para a amplificação das amostras consiste em uma denaturação inicial de $95^{\circ} \mathrm{C}$ por 10 minutos, seguidos de 40 ciclos de $95^{\circ} \mathrm{C}$ por 15 segundos (denaturação) e $60^{\circ} \mathrm{C}$ por 1 minuto (anelamento dos primers e extensão). 
No final de todas as reações, as curvas de dissociação com temperaturas crescentes foram analisadas, a fim de verificar a amplificação de um único produto. As condições da reação foram idênticas às utilizadas para a construção das curvas de calibração e otimização dos primers. As amostras foram estudadas em duplicata e, para cada gene do estudo, foram amplificadas em paralelo as amostras controle cDNA. Todas as reações de PCR, consideradas para análise, apresentaram eficiência igual ou superior a 95\%.

A expressão dos genes escolhidos para este estudo foi normalizada em relação ao RNA mensageiro dos genes endógenos, GAPDH e beta-actina, conforme descrito anteriormente,e por Livak et al., ${ }^{43}$ em 2001. Os primers utilizados estão descritos na tabela 1.

Tabela 1 - Primers usados para avaliar os receptores $\beta$-adrenérgicos

\begin{tabular}{|c|c|c|c|c|}
\hline & Primer & Seqüências de oligonucleotídeos & $\begin{array}{c}\text { Tamanho } \\
\text { do produto }\end{array}$ & Referência \\
\hline \multirow{2}{*}{ RA- $\beta 1$} & Forward & 5'CTGCTACAACGACCCCAAGTG3' & \multirow[t]{2}{*}{ 120pb } & \multirow[t]{2}{*}{ Sato et al. ${ }^{44}$} \\
\hline & Reverse & 5'AACACCCGGAGGTACACGAA 3' & & \\
\hline \multirow{2}{*}{$R A-\beta 2$} & Forward & 5'GAGCCACACGGGAATGACA 3' & \multirow[t]{2}{*}{$133 \mathrm{pb}$} & \multirow[t]{2}{*}{ Sato et al. ${ }^{44}$} \\
\hline & Reverse & 5'CCAGGACGATAACCGACATGA3' & & \\
\hline \multirow{2}{*}{ GAPDH } & Forward & 5'ATGTATCCGTTGTGGATCTGAC3' & \multirow[t]{2}{*}{$78 \mathrm{pb}$} & \multirow[t]{2}{*}{ Bai e Meng ${ }^{45}$} \\
\hline & Reverse & 5'CCTGCTTCACCACСTTCTTG3' & & \\
\hline \multirow{2}{*}{ Beta-actina } & Forward & 5'GTGCTATGTTGCCCTAGACTTCG3' & \multirow[t]{2}{*}{$175 \mathrm{pb}$} & \multirow[t]{2}{*}{ Yüzbasioglu et al. ${ }^{46}$} \\
\hline & Reverse & 5'GATGCCACAGGATTCCATACCC3' & & \\
\hline
\end{tabular}




\subsubsection{Catecolaminas periféricas}

Para a quantificação da adrenalina e da noradrenalina periféricas, foi utilizado o kit 3-CAT Research ELISA (ensaio imunoenzimático) da empresa LDN (Labor Diagnostika Nord), seguindo o protocolo do fabricante.

Os reagentes foram tirados da geladeira e permaneceram em TA, durante 30 minutos antes do início do protocolo. Foram pipetados $30 \mu \mathrm{L}$ de plasma, reagentes padrão e controles nos poços da placa de extração, cada amostra em duplicata. Em seguida, foram adicionados $50 \mu \mathrm{L}$ dos reagentes Assay Buffer e Extraction Buffer em cada poço, sendo a placa então tampada e levada para incubação e agitação (600 rpm) em TA, durante 1 hora. Após esse período, foi removido todo o líquido da placa que foi lavada com o reagente Wash Buffer. Então, $150 \mu \mathrm{L}$ de Acylation Buffer e $25 \mu \mathrm{L}$ de Acylation Solution foram colocados em todos os poços e a placa, mais uma vez, foi levada para incubação e agitação (600 rpm) em TA, durante 20 minutos. Após essa nova incubação, o líquido foi removido e a placa lavada mais duas vezes com o Wash Buffer. Depois desse passo, foram adicionados, em cada poço, $200 \mu \mathrm{L}$ de ácido clorídrico e a placa levada para incubação e agitação (600 rpm) em TA, durante 10 minutos.

A fase de extração estava finalizada e iniciou-se a fase de conversão enzimática. Em uma nova placa, foram colocados $190 \mu \mathrm{L}$ de cada amostra extraída e adicionados $50 \mu \mathrm{L}$ de Enzyme Solution. A placa foi levada para uma agitação de 1 minuto e, então, colocada para incubação durante 2 horas em estufa ajustada à temperatura de $37^{\circ} \mathrm{C}$. Após esse período, $75 \mu \mathrm{L}$ de reagente 
padrão, controles e amostras foram colocados em outras duas placas, uma de adrenalina e uma de noradenalina. Então, $50 \mu \mathrm{L}$ de Antiserum de adrenalina e noradrenalina foram adicionados em cada poço das placas específicas para cada uma das catecolaminas e essas placas foram colocadas para nova incubação, de 15-20 horas, em geladeira.

No dia seguinte a essa incubação, as placas foram retiradas da geladeira e foram novamente lavadas com Wash Buffer sendo, então, adicionados $100 \mu \mathrm{L}$ de Enzyme Conjugate em todos os poços e novamente as placas foram para incubação e agitação (600 rpm) em TA, durante 30 minutos. Após uma última lavagem com o Wash Buffer, foram adicionados $100 \mu \mathrm{L}$ do reagente Substrate e novamente incubação e agitação (600rpm) em TA, durante 30 minutos, porém dessa vez protegidas da luz. Depois desse período de incubação, foram adicionados $100 \mu \mathrm{L}$ de Stop Solution. A leitura da absorbância foi realizada em equipamento próprio no comprimento de luz de $450 \mathrm{~nm}$.

\subsubsection{Catecolaminas miocárdicas}

As catecolaminas foram extraídas dos fragmentos, através de maceração (mecânica) em ácido perclórico $0,1 \mathrm{M}$, concentradas em alumina e eluídas com solução de ácido acético $0,1 \mathrm{~N}$. Os eluatos foram analisados em seu conteúdo de catecolaminas através, de cromatografia líquida de alta performance (HPLC). O resultado final foi expresso em pg de catecolaminas por $\mathrm{mL}$. 


\subsubsection{Quantificação}

O tecido cardíaco foi macerado com $100 \mu \mathrm{L}$ de ácido perclórico 0,1 M e sonicado por 15 minutos \pm 2 minutos, adicionados $50 \mu \mathrm{L}$ de dihidroxibenzilamina (DHBA) $10 \mathrm{ng} / \mathrm{mL}$ e $250 \mu \mathrm{L}$ de ácido perclórico $0,1 \mathrm{M} \mathrm{e}$, então, centrifugado por 15 minutos a $4^{\circ} \mathrm{C}$ e $3.000 \mathrm{rpm}$. O sobrenadante foi transferido para outro microtubo e adicionados $350 \mu \mathrm{L}$ de tampão Tris $1 \mathrm{M}$. Foram adicionados cerca de $10 \mathrm{mg}$ de alumina e procedida a extração das catecolaminas. As amostras extraídas foram injetadas no HPLC eletroquímico, conforme instruções do fabricante.

\subsection{Análise estrutural}

\subsubsection{Tamanho do miócito}

Após a remoção do coração, o mesmo foi dividido em base, 1/3 médio e ápice sendo o $1 / 3$ médio fixado em formol a $10 \%$ e emblocado em parafina e o restante conservado em nitrogênio líquido. Os corações em parafina foram submetidos a cortes transversais em secções de $4 \mu \mathrm{m}$, ao nível do equador, de modo a analisar ventrículo direito e esquerdo. Foram colocados em lâmina silanizada, para evitar seu descolamento, durante os procedimentos histológicos. Os cortes do coração foram corados por hematoxilina-eosina (HE).

A quantificação do tamanho do miócito foi realizada, observando-se sempre cortes longitudinais, onde os núcleos estavam ovais e centralizados. $O$ diâmetro, então, foi medido em $\mu \mathrm{m}$ com o auxílio de um microscópio óptico, 
acoplado a um computador com o programa QWIN Image Processing and Analysis Software (Leica Microsystems Cambridge Ltd.) (figura 3).

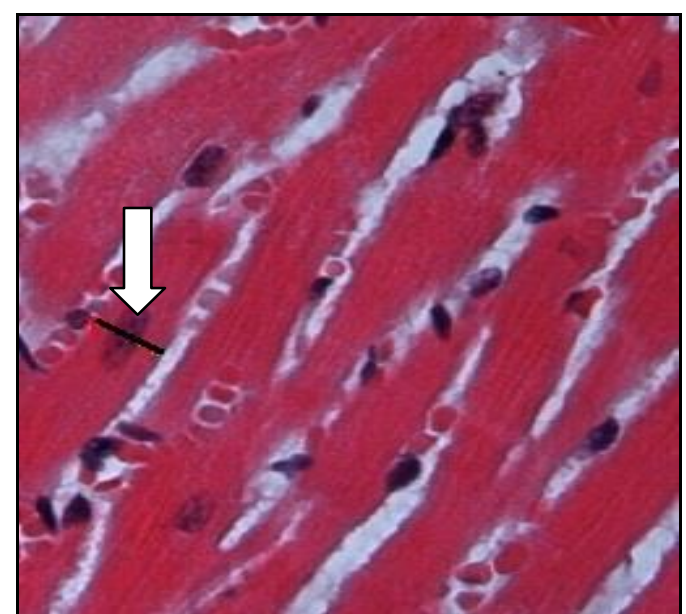

Figura 3 - Corte corado em hematoxilina-eosina do miócito ilustrando sua medida

\subsection{Análise estatística}

Para verificar a associação entre as variáveis qualitativas foi utilizado o teste exato de Fisher ou teste Qui-quadrado.

O teste de Kolmogorov-Smirnov foi utilizado para evidenciar a normalidade dos dados e, quando a normalidade não foi rejeitada, realizou-se o teste paramétrico.

O teste t-Student pareado, ou teste de Wilcoxon pareado, foi utilizado para verificar se houve modificação ao longo do tempo.

O teste ANOVA ou Kruskal-Wallis foi utilizado para comparar se mais de dois grupos são iguais. Caso houvesse significância estatística foi utilizado teste de comparações múltiplas (Tukey nos dados paramétricos e Brunner nos não 
paramétricos) para verificar quais pares de grupos se diferenciaram. O nível de significância adotado foi de $5 \%(p<0,05)$. 
4. RESULTADOS 
Foram incluídos 15 animais em cada grupo. Entretanto, o grupo UNI teve $13 \%$ de mortalidade, ficando com 13 animais; o grupo UNIA teve $7 \%$ de mortalidade, restando 14 animais e o grupo BIL, com $77 \%$ de mortalidade (31 animais operados), terminou com 7 animais. Para cada variável analisada, foram incluídos todos os sobreviventes, exceto o teste de esforço máximo aeróbio e a avaliação da modulação autonômica, onde foram incluídos aleatoriamente apenas 5 animais de cada grupo (CT, CTAT, UNI e UNIA) e 7 animais do grupo BIL, para suprir eventuais óbitos durante a canulação da carótida.

\subsection{Variáveis eletrocardiográficas}

Nas variáveis eletrocardiográficas não houve diferença entre os grupos quanto ao ritmo sinusal (CT: $86 \%$; CTAT: $93 \%$; UNI: 100\%; UNIA: 75\%; BIL: $85 \%$, $p=0,5)$. A frequência cardíaca mostrou diferença somente entre os grupos CTAT $(266 \mathrm{bpm} \pm 25) \times \mathrm{UNI}(308 \mathrm{bpm} \pm 35) \mathrm{com} \mathrm{p}=0,0185$ (figura 4). Os intervalos PR e QTc não tiveram diferenças entre os grupos (tabela 2). 
Resultados

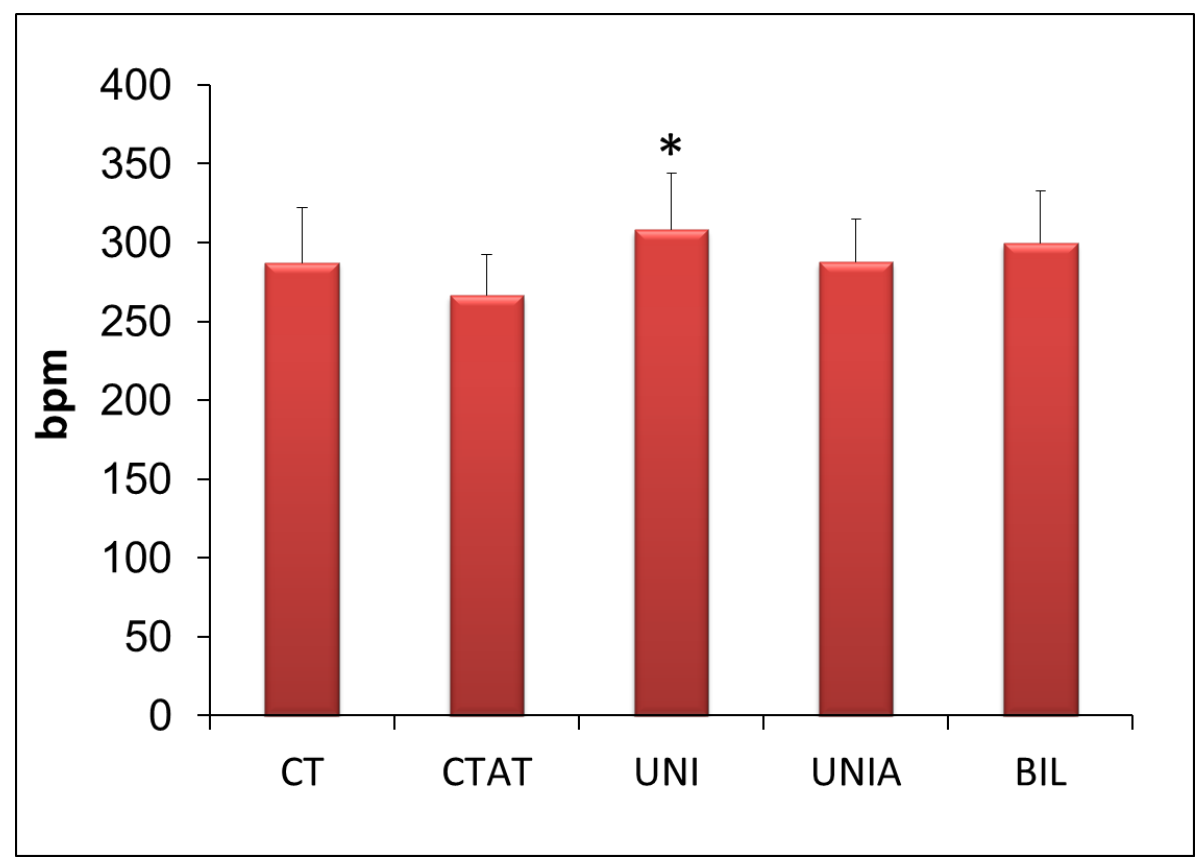

Figura 4 - Frequência cardíaca após 6 semanas

${ }^{*} \mathrm{p}=0,0185$ (CTAT vs. UNI).

CT: controle (n: 15); CTAT: controle com atenolol ( $\mathrm{n}: 15)$; UNI: simpatectomia unilateral esquerda ( $n$ : 13); UNIA: simpatectomia unilateral esquerda com atenolol ( $\mathrm{n}$ : 14); BIL: simpatectomia bilateral $(\mathrm{n}: 7)$

Tabela 2 - Intervalo PR e QTc sem diferença entre os grupos

\begin{tabular}{c|c|c|c|c|c|c}
\hline & CT & CTAT & UNI & UNIA & BIL & p \\
\hline Intervalo PR (ms) & $57,20 \pm 3,91$ & $59 \pm 4,02$ & $57,33 \pm 4,10$ & $54,83 \pm 7,88$ & $53 \pm 6,83$ & 0,06 \\
\hline Intervalo QTc (ms) & $\begin{array}{c}207,53 \pm \\
20,01\end{array}$ & $\begin{array}{c}212,33 \pm \\
33,95\end{array}$ & $\begin{array}{c}213,50 \pm \\
29,01\end{array}$ & $\begin{array}{c}206,50 \pm \\
27,33\end{array}$ & $\begin{array}{c}218 \pm \\
16,01\end{array}$ & 0,85 \\
\hline
\end{tabular}

CT: controle; CTAT: controle com atenolol; UNI: simpatectomia unilateral esquerda; UNIA: simpatectomia unilateral esquerda com atenolol; BIL: simpatectomia bilateral; ms: milissegundo 


\subsection{Variáveis ecocardiográficas}

O diâmetro sistólico final do ventrículo esquerdo (DS) foi maior no grupo CTAT $(4,8 \mathrm{~mm} \pm 0,6) \times \operatorname{UNI}(3,8 \mathrm{~mm} \pm 0,7)(p=0,0059)$ e CTAT $\times$ BIL $(3,4 \mathrm{~mm} \pm 0,5)$ $(p=0,0001)$ (figura 5). O diâmetro diastólico final do ventrículo esquerdo (DD) também foi maior no grupo CTAT $(8,1 \mathrm{~mm} \pm 0,4) \times$ UNI $(7,0 \mathrm{~mm} \pm 0,7)$ $(p=0,0001)$ e CTAT $\times$ BIL $(7,1 \mathrm{~mm} \pm 0,6)(p=0,0008)$ (figura 5). A FE foi menor no grupo CTAT $(76 \% \pm 6) \times$ BIL $(87 \% \pm 4)(p=0,0004)$, apesar de se manter normal (figura 6). Não observamos diferença entre os grupos nas variáveis TRIV $(p=0,4945)$ e IPM $(p=0,0679)$ (tabela 3$)$.

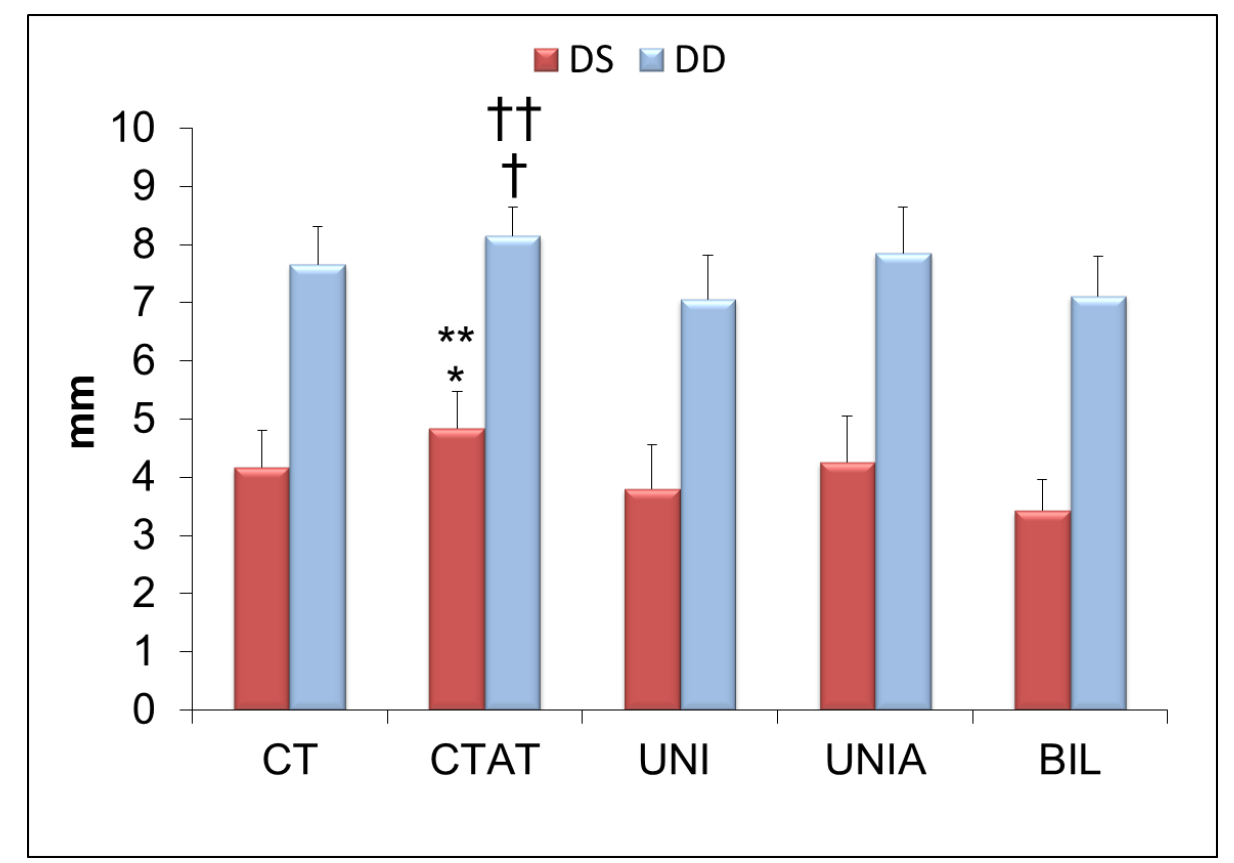

Figura 5 - Diâmetro sistólico e diastólico final do ventrículo esquerdo ${ }^{*} \mathrm{p}=0,0059$ (CTAT vs. UNI) $\mathrm{e}^{* *} \mathrm{p}=0,0001$ (CTAT vs.BIL). $\dagger \mathrm{p}=0,0001$ (CTAT vs. UNI) e $\uparrow+p=0,0008$ (CTAT vs. BIL)

CT: controle ( $n: 15)$; CTAT: controle com atenolol ( $n$ : 15); UNI: simpatectomia unilateral esquerda (n: 13); UNIA: simpatectomia unilateral esquerda com atenolol ( $n$ : 14); BIL: simpatectomia bilateral $(n: 7)$ 
Tabela 3 - Variáveis ecocardiográficas

\begin{tabular}{c|c|c|c|c|c|c}
\hline & CT & CTAT & UNI & UNIA & BIL & p \\
\hline TRIV (ms) & $35,17 \pm 8,89$ & $33,38 \pm 5,38$ & $34,63 \pm 6,48$ & $36,78 \pm 8,6$ & $30,86 \pm 8,05$ & 0,49 \\
\hline IPM & $0,73 \pm 0,29$ & $0,88 \pm 0,14$ & $0,78 \pm 0,22$ & $0,85 \pm 0,20$ & $0,62 \pm 0,28$ & 0,06 \\
\hline
\end{tabular}

CT: controle (n: 15); CTAT: controle com atenolol (n: 15); UNI: simpatectomia unilateral esquerda (n: 13); UNIA: simpatectomia unilateral esquerda com atenolol ( $n: 14)$; BIL: simpatectomia bilateral $(n: 7)$; TRIV: tempo de relaxamento isovolumétrico; IPM: índice de performance miocárdica

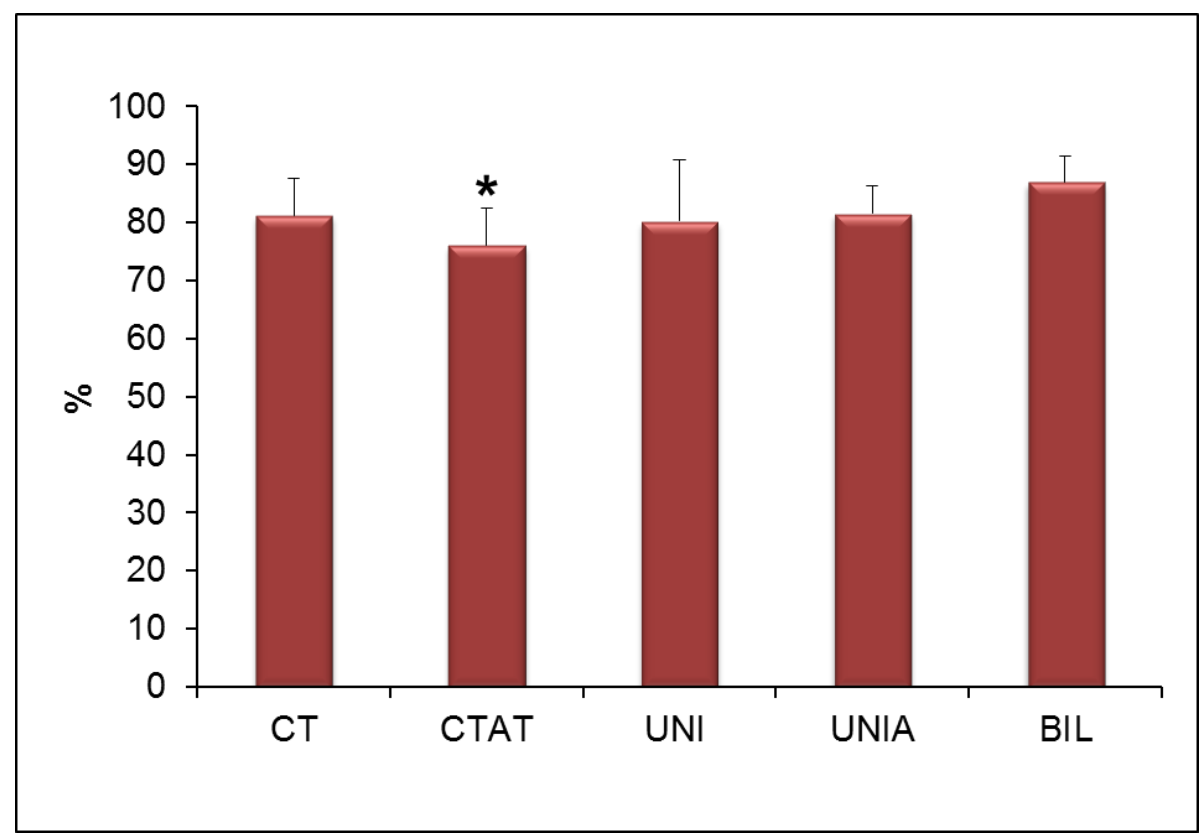

Figura 6 - Fração de ejeção do ventrículo esquerdo

${ }^{*} \mathrm{p}=0,0004$ (CTAT vs. BIL).

CT: controle (n: 15); CTAT: controle com atenolol (n: 15); UNI: simpatectomia unilateral esquerda (n: 13); UNIA: simpatectomia unilateral esquerda com atenolol (n:14); BIL: simpatectomia bilateral $(n: 7)$

\subsection{Análises da modulação autonômica}

Na análise da modulação autonômica, não houve diferença entre os grupos para as variáveis DP IP, VAR IP, VAR PAS, BF e o índice a da BF. Ainda assim, observamos que a BF e o índice $\alpha$ da BF apresentam $p=0,09$ e $p=0,07$, respectivamente, sendo mais expressivos nos grupos com 
simpatectomia sem atenolol (BIL e UNI) (tabela 4). Contudo, a AF apresentou diferença entre o CT e CTAT, UNIA e BIL (figura 7).

Tabela 4 - Variáveis de modulação autonômica

\begin{tabular}{l|c|c|c|c|c|c}
\hline & CT & CTAT & UNI & UNIA & BIL & P \\
\hline DP IP & $10,39 \pm 4,92$ & $9,69 \pm 0,96$ & $11,02 \pm 5,15$ & $9,82 \pm 2,3$ & $9,97 \pm 4,68$ & 0,71 \\
\hline VAR IP & $\begin{array}{c}127,22 \pm \\
110,98\end{array}$ & $94,56 \pm 18,6$ & $\begin{array}{c}142,7 \pm \\
91,47\end{array}$ & $\begin{array}{c}100,72 \pm \\
40,68\end{array}$ & $116,84 \pm 127,12$ & 0,69 \\
\hline VAR PAS & $\begin{array}{c}44,32 \pm \\
31,27\end{array}$ & $29,15 \pm 5,63$ & $\begin{array}{c}95,52 \pm \\
112,99\end{array}$ & $\begin{array}{c}30,18 \pm \\
13,52\end{array}$ & $53,97 \pm 29,85$ & 0,11 \\
\hline BF & $4,49 \pm 3,08$ & $3,48 \pm 1,33$ & $7,24 \pm 1,81$ & $4,12 \pm 2,88$ & $9,92 \pm 8,87$ & 0,09 \\
\hline $\begin{array}{l}\text { Índice a da } \\
\text { BF }\end{array}$ & $1,59 \pm 1,42$ & $1,58 \pm 0,42$ & $1,03 \pm 0,55$ & $2,03 \pm 0,55$ & $1,04 \pm 0,51$ & 0,07 \\
\hline
\end{tabular}

CT: controle ( $n$ : 5); CTAT: controle com atenolol ( $\mathrm{n}$ : 5); UNI: simpatectomia unilateral esquerda (n: 5); UNIA: simpatectomia unilateral esquerda com atenolol ( $n$ : 5); BIL: simpatectomia bilateral ( $n$ : 7); DP IP: desvio padrão do intervalo de pulso; VAR IP: variância do intervalo de pulso; VAR PAS: variância da pressão arterial sistólica; BF: baixa frequência; Índice $\alpha$ da BF: índice $\alpha$ da baixa frequência

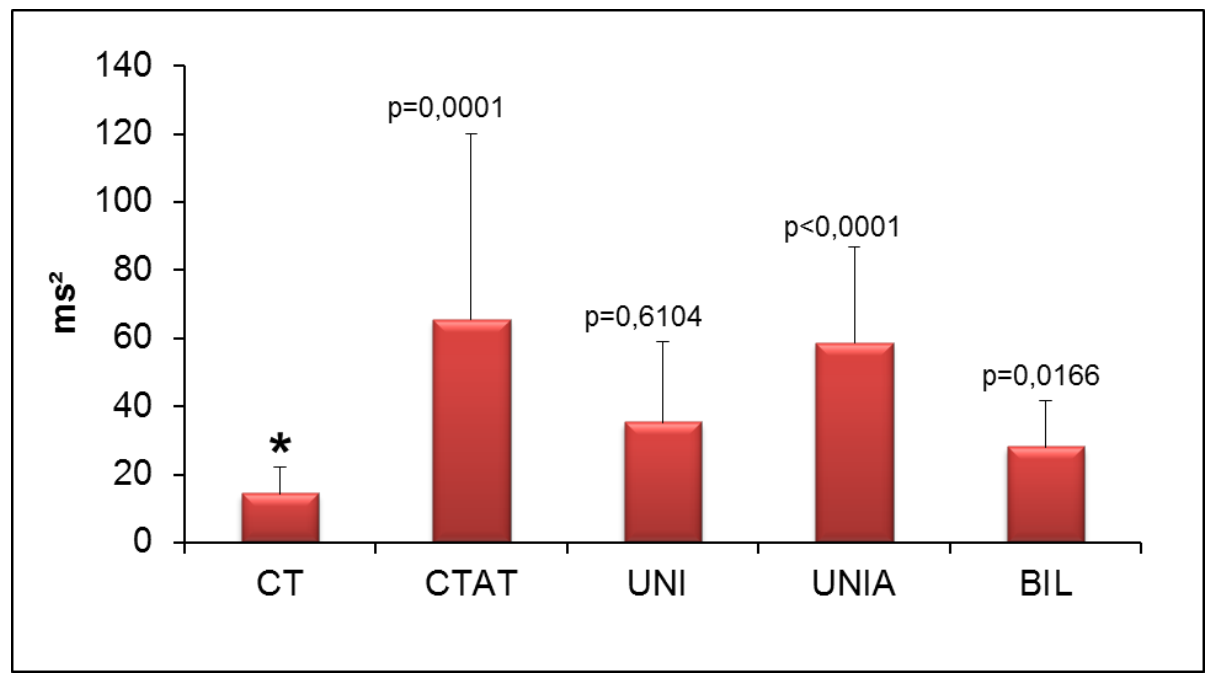

Figura 7 - Variável alta frequência da análise de modulação autonômica com valores de $\mathrm{p}$ significativos em todos os grupos comparados ao CT, exceto UNI

CT: controle ( $n: 5)$; CTAT: controle com atenolol ( $n$ : 5); UNI: simpatectomia unilateral esquerda (n: 5); UNIA: simpatectomia unilateral esquerda com atenolol ( $n$ : 5); BIL: simpatectomia bilateral $(n: 7)$ 


\subsection{Análises do teste de esforço máximo aeróbio}

Ao teste de esforço, as variáveis tempo, velocidade máxima atingida e distância não apresentaram diferenças entre os grupos (tabela 5).

Tabela 5 - Variáveis do teste de esforço máximo aeróbio sem diferença estatística

\begin{tabular}{c|c|c|c|c|c|c}
\hline & CT & CTAT & UNI & UNIA & BIL & p \\
\hline $\begin{array}{c}\text { Tempo } \\
\text { (minutos) }\end{array}$ & $9,8 \pm 2,7$ & $10,2 \pm 1,8$ & $10,0 \pm 2,0$ & $8,9 \pm 2,4$ & $8,1 \pm 1,8$ & 0,32 \\
\hline $\begin{array}{c}\text { Velocidade } \\
\text { máxima (Km/h) }\end{array}$ & $1,2 \pm 0,3$ & $1,2 \pm 0,2$ & $1,2 \pm 0,2$ & $1,2 \pm 0,3$ & $1,2 \pm 0,2$ & 0,33 \\
\hline Distância (Km) & $0,13 \pm 0,06$ & $0,13 \pm 0,04$ & $0,13 \pm 0,04$ & $0,11 \pm 0,05$ & $0,09 \pm 0,03$ & 0,48 \\
\hline
\end{tabular}

CT: controle ( $n$ : 5); CTAT: controle com atenolol ( $\mathrm{n}$ : 5); UNI: simpatectomia unilateral esquerda ( $\mathrm{n}$ : 5); UNIA: simpatectomia unilateral esquerda com atenolol (n: 5); BIL: simpatectomia bilateral ( $\mathrm{n}: 7$ )

$\mathrm{Na}$ análise da pressão arterial ao repouso houve diferença entre os grupos. A PAS foi maior no grupo BIL $(144 \mathrm{mmHg} \pm 8) \times$ UNIA $(128 \mathrm{mmHg} \pm 5)$ com $p<0,0001$ (figura 8). A pressão arterial diastólica (PAD) também foi maior no grupo BIL $(110 \mathrm{mmHg} \pm 7) \times$ UNIA $(94 \mathrm{mmHg} \pm 5)$ com $\mathrm{p}=0,0016$ (figura 8). Contudo, a pressão arterial média (PAM) não mostrou diferença entre os grupos $(p=0,06)$. Comparando 0 grupo CT com 0 BIL, a PAS (CT: $130 \mathrm{mmHg} \pm 9, \mathrm{p}=0,09)$ e a PAD (CT: $98 \mathrm{mmHg} \pm 9, \mathrm{p}=0,37$ ) eram maiores no grupo BIL, a despeito de não haver diferença estatística entre os dois grupos. 


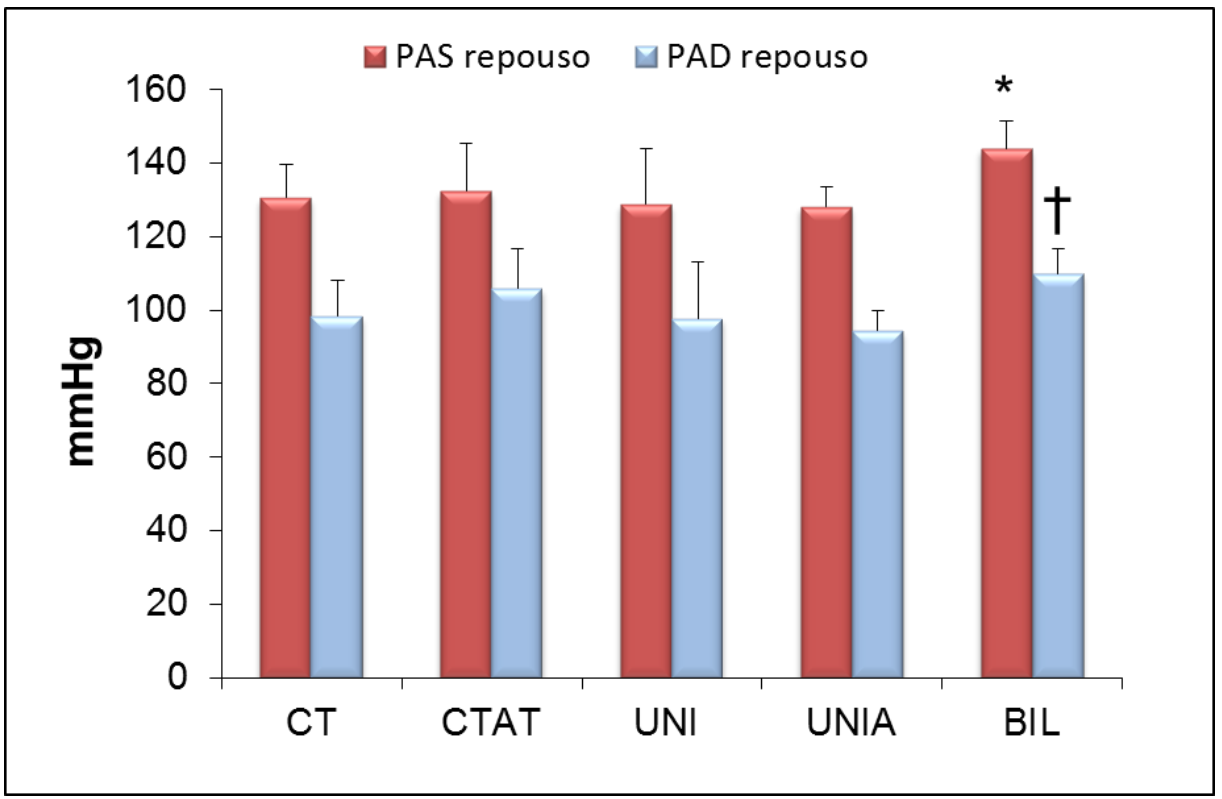

Figura 8 - Pressão arterial sistólica e diastólica em repouso

${ }^{*} \mathrm{p}<0,0001$ (BIL vs. UNIA)

$\mathrm{tp}=0,0016$ (BIL vs. UNIA)

CT: controle (n: 5); CTAT: controle com atenolol (n: 5); UNI: simpatectomia unilateral esquerda (n: 5); UNIA: simpatectomia unilateral esquerda com atenolol (n: 5); BIL: simpatectomia bilateral ( $\mathrm{n}: 7)$

$\mathrm{Na}$ avaliação da FC, imediatamente antes do teste de esforço, o grupo

BIL (421 bpm \pm 25$)$ teve maiores valores em relação a todos os grupos, exceto o UNI ( $p=0,9979)$ (figura 9). 


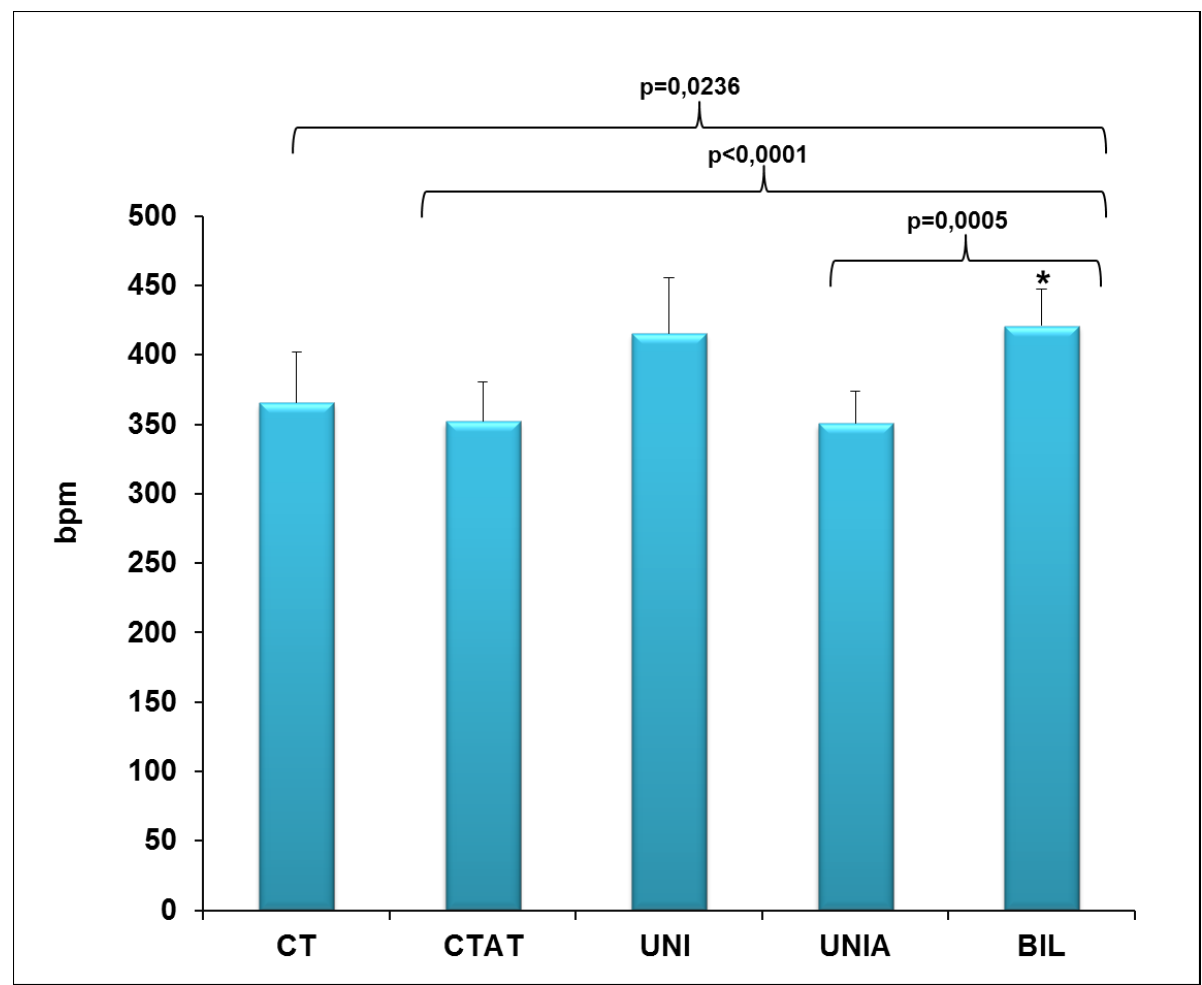

Figura 9 - Frequência cardíaca em repouso com valores de $p$ significativos em todos os grupos comparados ao BIL, exceto UNI

CT: controle (n: 5); CTAT: controle com atenolol (n: 5); UNI: simpatectomia unilateral esquerda ( $n$ : 5); UNIA: simpatectomia unilateral esquerda com atenolol ( $n$ : 5); BIL: simpatectomia bilateral ( $\mathrm{n}: 7)$

$\mathrm{Na}$ análise das mesmas variáveis, no pico do esforço, observou-se a PAD maior no grupo BIL x UNIA ( $p<0,0001$; figura 10 ), o mesmo na PAM BIL $x$ UNIA ( $p=0,0134$; figura 10$)$. Comparando o grupo CT com o BIL, a PAD (CT: $93 \mathrm{mmHg} \pm 13, \mathrm{p}=0,08)$ e a PAM (CT: $104 \mathrm{mmHg} \pm 13, \mathrm{p}=0,08$ ), apresentaram-se maiores no grupo BIL, a despeito de não haver diferença estatística entre esses dois grupos. Não houve diferença entre os grupos na PAS (CT: 124,94 \pm 14,6 mmHg; CTAT: 128,16 \pm 6,92 mmHg; UNI: 131,74 \pm 11,07 mmHg; UNIA: 125,12 $\pm 9,09 \mathrm{mmHg}$; BIL: 143,38 $\pm 10,13 \mathrm{mmHg} ; \mathrm{p}=0,05)$, apesar das médias serem maiores nos grupos simpatectomizados sem atenolol com valor de $p=0,05$. 


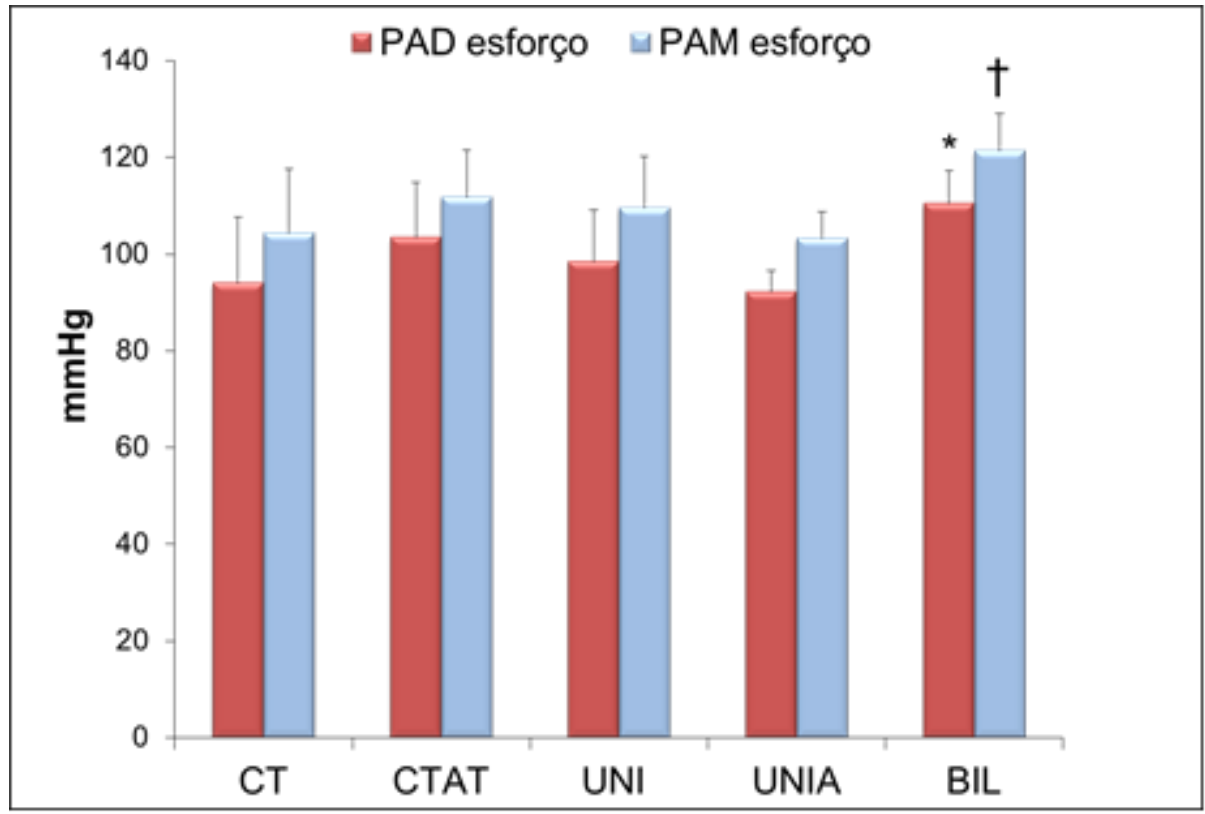

Figura 10 - Pressão arterial diastólica e média no pico do esforço ${ }^{*} \mathrm{p}<0,0001$ (BIL vs. UNIA), † $\mathrm{p}=0,0134$ (BIL vs. UNIA)

CT: controle (n: 5); CTAT: controle com atenolol (n: 5); UNI: simpatectomia unilateral esquerda (n: 5); UNIA: simpatectomia unilateral esquerda com atenolol ( $n: 5)$; BIL: simpatectomia bilateral ( $\mathrm{n}: 7)$

$\mathrm{Na}$ avaliação da FC, no pico do esforço, o grupo BIL apresentou valores maiores, quando comparado a todos os grupos, exceto o UNI $(p=0,1681 ;$ figura 11). 


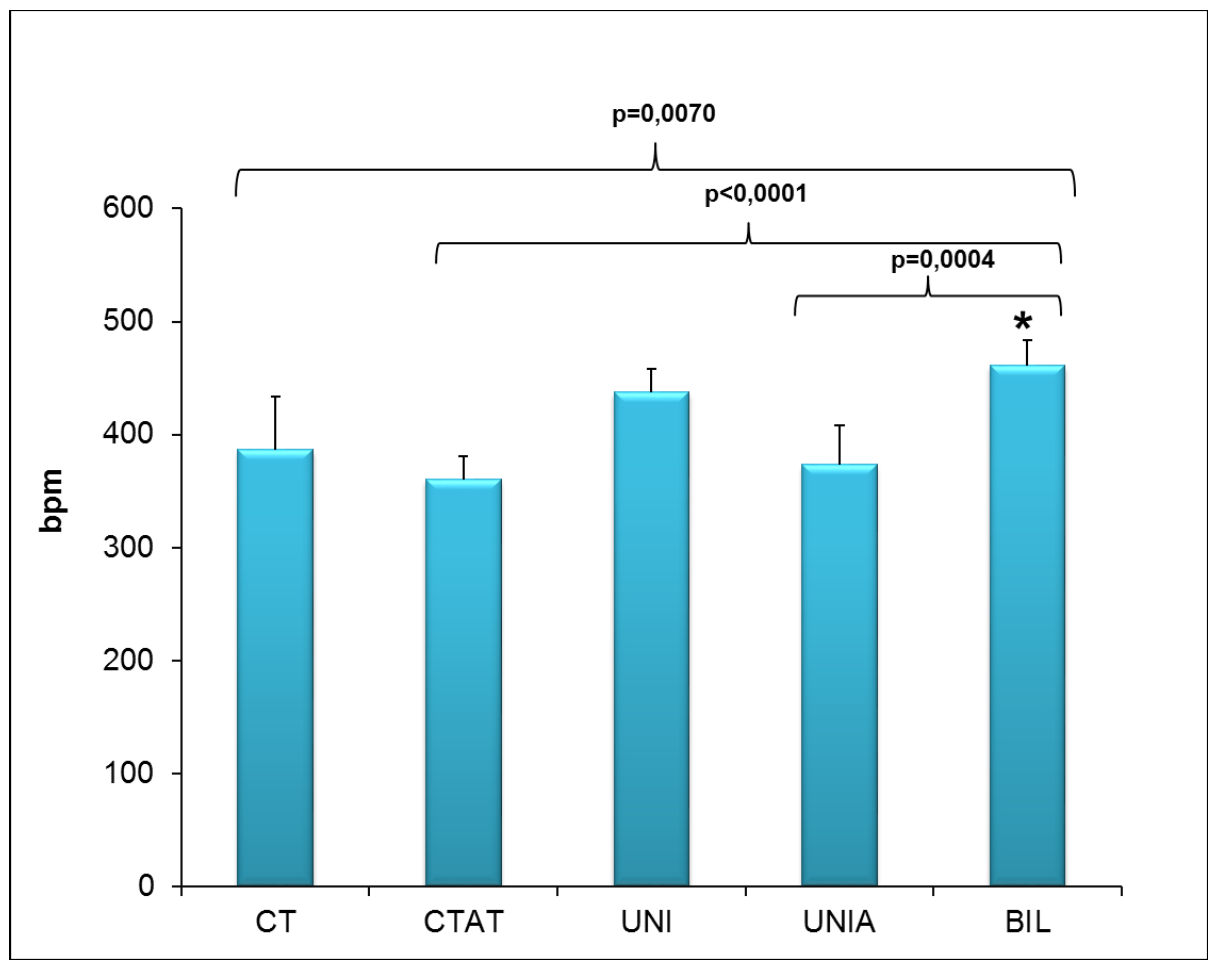

Figura 11 - Frequência cardíaca no pico do esforço com valores de $\mathrm{p}$ significativos em todos os grupos comparados ao BIL exceto UNI

CT: controle (n: 5); CTAT: controle com atenolol (n: 5); UNI: simpatectomia unilateral esquerda ( $\mathrm{n}$ : 5); UNIA: simpatectomia unilateral esquerda com atenolol ( $\mathrm{n}: 5)$; BIL: simpatectomia bilateral $(\mathrm{n}: 7)$

\subsection{Receptores $\beta 1$ e $\beta 2$}

$\mathrm{Na}$ análise dos receptores $\beta 1$ no $\mathrm{VE}$, não houve diferença entre os grupos no ápice $(p=0,1957)$, nem na base $(p=0,1183)$ (figura 12). Observou-se que, na análise de receptores $\beta 2$ no ápice do VE, houve maior concentração no grupo CT x UNIA ( $p=0,0086)$. O mesmo se repetiu na base do VE, com diferença entre CT x UNIA ( $p=0,0183)$ (figura 13). 


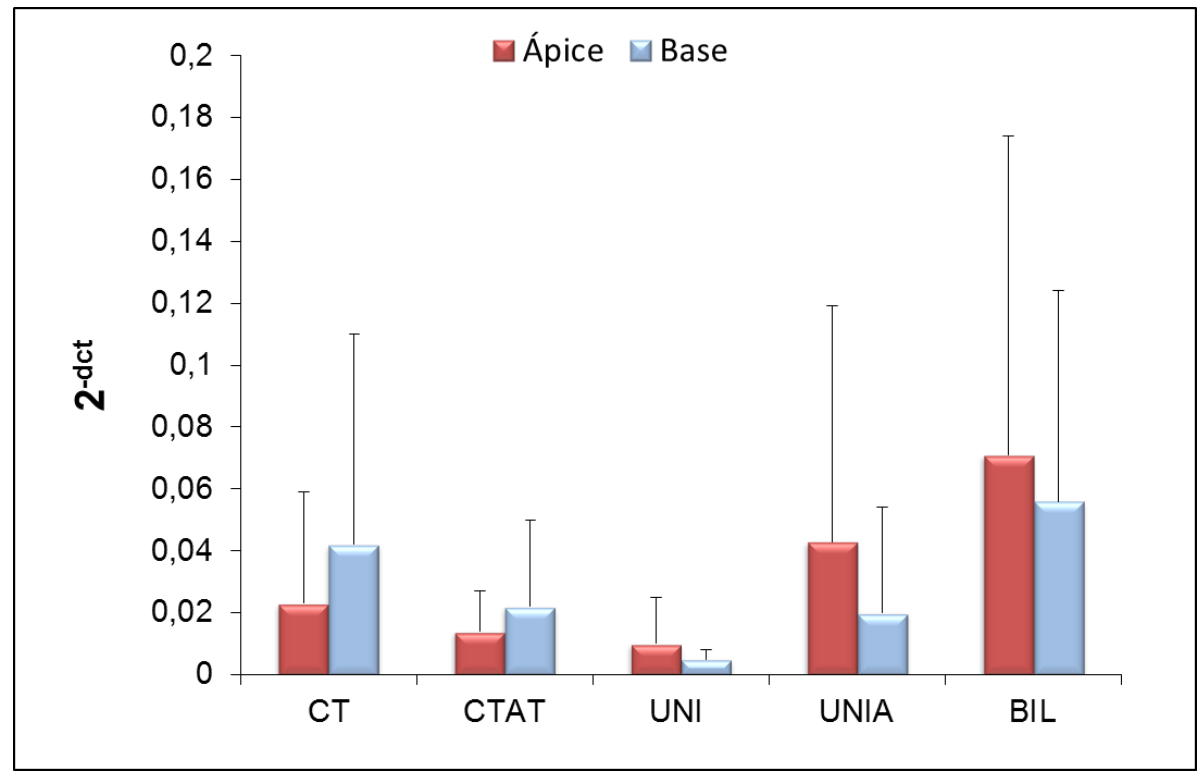

Figura 12 - Receptores $\beta 1$ no ápice $(p=0,19)$ e na base $(p=0,11)$ do VE, sem diferença entre os grupos

CT: controle (n: 15); CTAT: controle com atenolol (n: 15); UNI: simpatectomia unilateral esquerda ( $n$ : 13); UNIA: simpatectomia unilateral esquerda com atenolol (n:14); BIL: simpatectomia bilateral $(n: 7)$

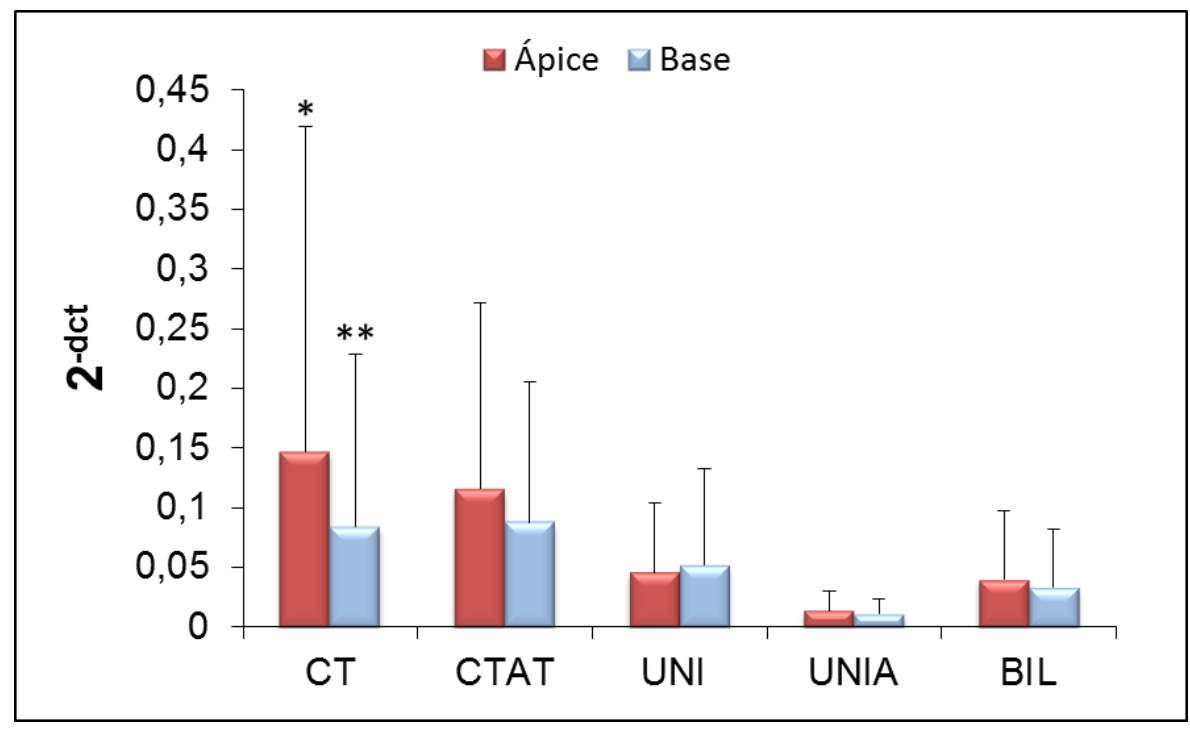

Figura 13 - Receptores $\beta 2$ no ápice, ${ }^{*} p=0,0086$ (CT vs. UNIA) e na base, ${ }^{* *} p=0,0183$ (CT vs. UNIA)

CT: controle (n: 15); CTAT: controle com atenolol ( $\mathrm{n}: 15)$; UNI: simpatectomia unilateral esquerda (n: 13); UNIA: simpatectomia unilateral esquerda com atenolol (n: 14); BIL: simpatectomia bilateral ( $\mathrm{n}: 7)$ 


\subsection{Catecolaminas periféricas}

Observou-se que a concentração sérica de adrenalina foi maior no grupo BIL em relação a todos os demais e também maior no grupo CTAT x CT $(p=0,0011)$ e UNI $\times C T(p<0,0001)$ (figura 14).

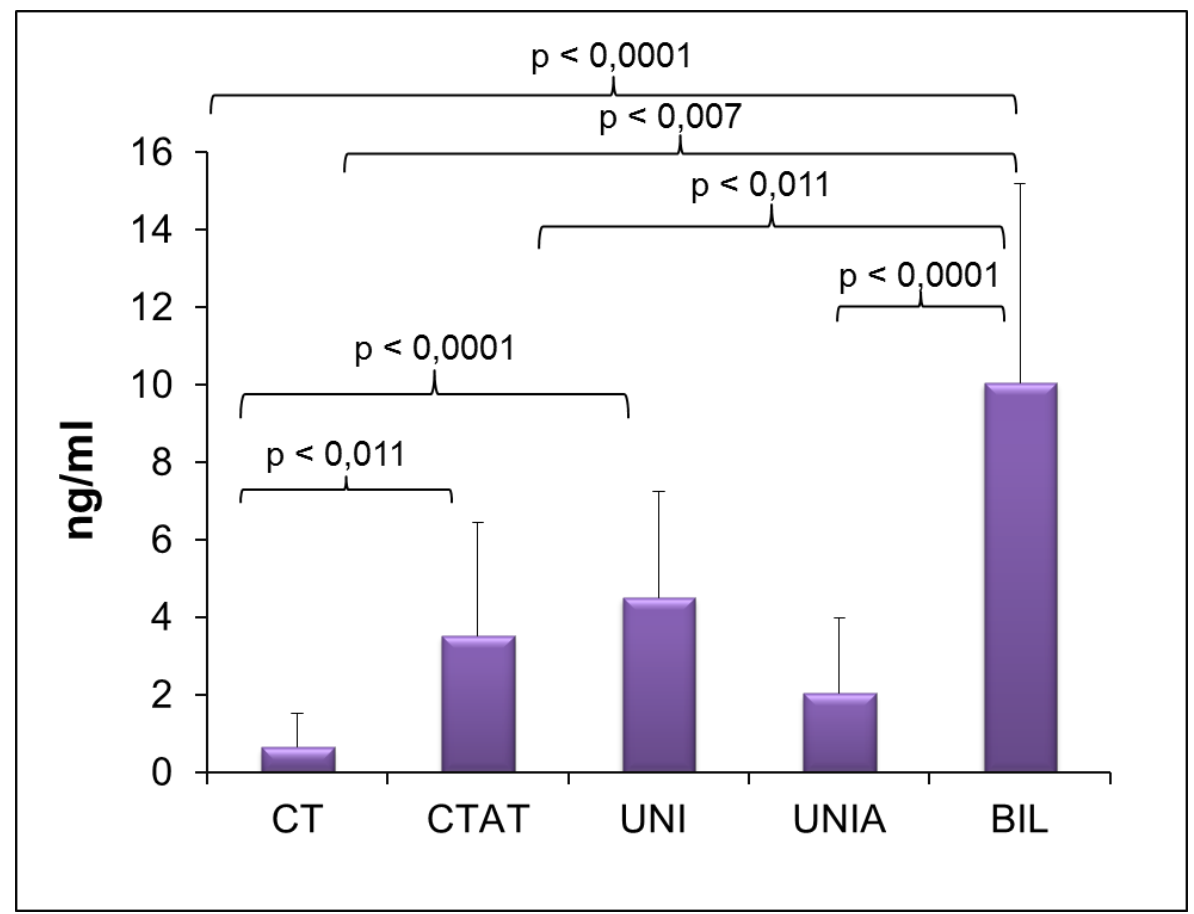

Figura 14 - Adrenalina periférica com valores de $p$ em relação ao grupo BIL com os demais

CT: controle (n: 15); CTAT: controle com atenolol ( $n: 15)$; UNI: simpatectomia unilateral esquerda ( $n$ : 13); UNIA: simpatectomia unilateral esquerda com atenolol ( $n: 14)$; BIL: simpatectomia bilateral ( $\mathrm{n}: 7)$

Observou-se que a concentração sérica de noradrenalina também foi maior no grupo BIL, em relação a todos os demais e, maior, no grupo UNI $x$ UNIA ( $p=0,0063)$ (figura 15). 


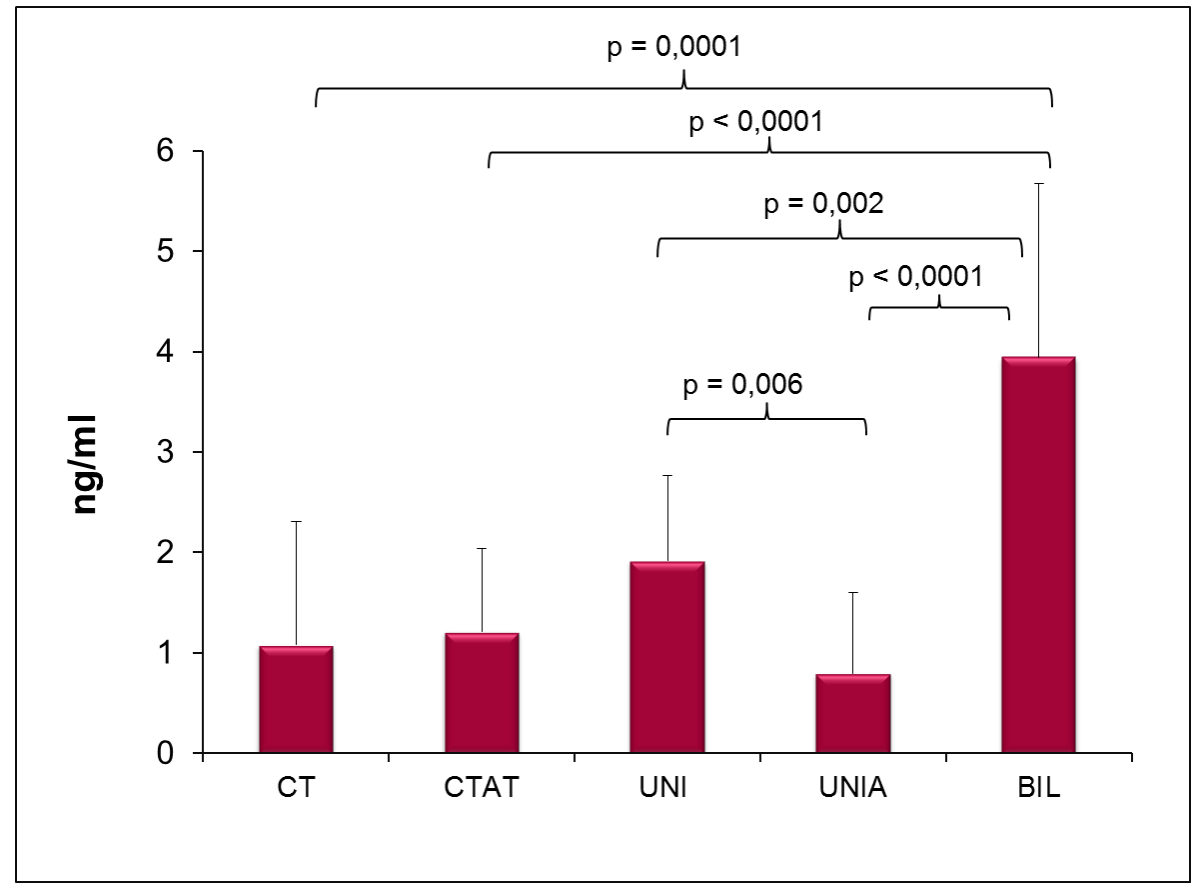

Figura 15 - Noradrenalina periférica com valores de $p$ em relação ao grupo BIL com os demais

${ }^{*} p=0,0001 ;+p<0,0001 ; \dagger p=0,0027 ; \pi p<0,0001 ; \varphi p=0,0063$. CT: controle (n: 15); CTAT: controle com atenolol ( $n$ : 15); UNI: simpatectomia unilateral esquerda ( $n$ : 13$)$; UNIA: simpatectomia unilateral esquerda com atenolol (n:14); BIL: simpatectomia bilateral $(\mathrm{n}: 7)$

\subsection{Catecolaminas miocárdicas}

$\mathrm{Na}$ análise da concentração miocárdica de catecolaminas, não houve diferenças entre os grupos na adrenalina, ou na noradrenalina (tabela 6).

Tabela 6 - Concentração miocárdica de catecolaminas

\begin{tabular}{l|c|c|c|c|c|c}
\hline & CT & CTAT & UNI & UNIA & BIL & p \\
\hline $\begin{array}{l}\text { Adrenalina } \\
\text { (ng/mL) }\end{array}$ & $24,3 \pm 28,5$ & $28,50 \pm 28,2$ & $12,0 \pm 0$ & $28,7 \pm 31,9$ & $12,0 \pm 0$ & 0,20 \\
\hline $\begin{array}{l}\text { Noradrenalina } \\
\text { (ng/mL) }\end{array}$ & $\begin{array}{c}1046,1 \pm \\
862,9\end{array}$ & $\begin{array}{c}1018,5 \pm \\
661,6\end{array}$ & $\begin{array}{c}277,8 \pm \\
316,80\end{array}$ & $\begin{array}{c}995,3 \pm \\
1119,5\end{array}$ & $\begin{array}{c}1.078,5 \pm \\
1.485,2\end{array}$ & 0,09 \\
\hline
\end{tabular}

CT: controle (n: 15); CTAT: controle com atenolol (n: 15); UNI: simpatectomia unilateral esquerda (n: 13); UNIA: simpatectomia unilateral esquerda com atenolol ( $n: 14)$; BIL: simpatectomia bilateral $(n: 7)$ 


\subsection{Tamanho do miócito}

$\mathrm{Na}$ análise do tamanho do miócito, não houve diferença entre os grupos (tabela 7).

Tabela 7 - Valores do tamanho do miócito

\begin{tabular}{c|c|c|c|c|c|c}
\hline & CT & CTAT & UNI & UNIA & BIL & p \\
\hline $\begin{array}{l}\text { Tamanho do } \\
\text { miócito }(\boldsymbol{\mu m})\end{array}$ & $11,28 \pm 1,92$ & $12,43 \pm 1,72$ & $11,33 \pm 2,08$ & $12,39 \pm 1,98$ & $11,61 \pm 1,53$ & 0,25 \\
\hline
\end{tabular}

CT: controle ( $n: 15)$; CTAT: controle com atenolol ( $n: 15)$; UNI: simpatectomia unilateral esquerda ( $n$ : 13); UNIA: simpatectomia unilateral esquerda com atenolol ( $\mathrm{n}: 14)$; BIL: simpatectomia bilateral $(\mathrm{n}: 7)$ 
5. DISCUSSÃO 
Embora existam inúmeras publicações sobre os efeitos da simpatectomia em modelos animais patológicos (infarto do miocárdio, taquicardiomiopatia induzida por marca-passo, bandagem da aorta para hipertrofia), dados em modelos fisiológicos são escassos. ${ }^{34,35}$

Neste cenário, optou-se por avaliar a resposta fisiológica deste procedimento, nas variáveis relacionadas ao sistema nervoso autônomo, como as propriedades cronotrópicas em repouso e ao esforço, a modulação autonômica cardiovascular, as catecolaminas miocárdicas e periféricas e os receptores beta-adrenérgicos do miocárdio. Também foram analisados os efeitos na função ventricular e no tamanho do miócito.

Em estudo que serviu de base para a simpatectomia na síndrome do QT longo, Yanovitz et al. ${ }^{47}$ avaliaram alterações eletrocardiográficas em cães tanto da simpatectomia por excisão do gânglio estrelado, quanto sua estimulação por eletrodos. Foi identificado prolongamento do intervalo QT após simpatectomia direita (20 a 70 ms) e discreta ou nenhuma alteração após simpatectomia esquerda. Quando realizada a estimulação do gânglio estrelado, o lado esquerdo respondeu com aumento no intervalo QT (10 a $90 \mathrm{~ms}$ ) e sem alterações com o estímulo no lado direito. Já, na avalição do QTc em humanos, Schwartz et al. ${ }^{48}$ relataram diminuição no intervalo QTc em média de $39 \pm 54$ ms, 6 meses após a denervação de pacientes com síndrome do QT longo. Collura et al. ${ }^{49}$ não encontraram diferença no intervalo QT, após simpatectomia esquerda em pacientes com síndrome do QT longo e taquicardia ventricular polimórfica catecolaminérgica. Considerando o ECG, nossa análise do intervalo 
QT não demonstrou diferenças entre os grupos. Nossos achados, considerando também a não uniformidade da literatura, nos levam a crer que o tônus simpático não é o principal fator, isoladamente, a influenciar este parâmetro do ECG.

Nas análises ecocardiográficas, Jiang et al. ${ }^{35}$ mostraram aumento nos volumes sistólico e diastólico com queda na FE no grupo simpatectomia química em comparação com os ratos do grupo controle. Schlack et al. ${ }^{50}$ mostraram, em modelo canino, que a simpatectomia esquerda altera agudamente a contratilidade regional do VE, atrasando a contração e o relaxamento da área denervada, em comparação com a área não denervada e levando à disfunção diastólica. O débito cardíaco (DC) e PA foram mantidos. Esse mesmo grupo repetiu o estudo ${ }^{51}$ em cães com IC induzida por marcapasso e mostrou piora expressiva da função diastólica e global do VE, com queda do DC.

No estudo de Perlini et al., ${ }^{52}$ em ratos com bandagem da aorta, divididos em grupos placebo, simpactectomia química com 6-hidroxidopamina, propranolol e doxazosina, quando comparados aos animais do grupo controle, todos os animais tratados ativamente mostraram menos hipertrofia, menos dilatação de VE e menos congestão pulmonar. No entanto, apenas os ratos tratados com o $\alpha$-bloqueio e a simpatectomia química tiveram menor grau de disfunção diastólica e melhor sobrevida nesse estudo. Em humanos, os dados de Lobato et al. ${ }^{53}$ não mostram diferenças nas funções sistólica e diastólica antes e após a simpatectomia por xylocaína unilateral esquerda ou direita em pacientes sem cardiopatia. Entretanto, Schlack e Dinter ${ }^{54}$ encontraram 
relaxamento ventricular prejudicado na simpatectomia esquerda, mas as alterações hemodinâmicas foram compensadas, e o DC foi mantido. Cruz et al. ${ }^{55}$ descreveram queda na FE (ainda dentro da normalidade) e alteração diastólica seis meses após simpatectomia para tratamento de hiperhidrose. Avaliando exclusivamente a ação do atenolol, Gonzenbach et al..$^{56}$ descreveram, em humanos, queda da fração de ejeção após quatro semanas de uso e nenhuma alteração no diâmetro diastólico, enquanto Otterstad et al. ${ }^{57}$ observaram aumento no diâmetro diastólico do VE.

Em nosso estudo, encontramos FE mais elevada no grupo BIL, provavelmente pelo estado hiperdinâmico secundário a maior atividade simpática periférica corroborada por outros achados (FC, níveis de catecolamina). A diferença estatística encontrada somente com o grupo CTAT pode ser atribuída ao efeito inotrópico negativo do beta bloqueador, como no estudo de Gonzenbach et al., ${ }^{56}$ em oposição ao estado hiperdinâmico do grupo BIL. Encontramos diferenças nos diâmetros em relação ao grupo CTAT, comparando com UNI e BIL, que também pode ser inferida da mesma forma que a FE (estado hiperdinâmico $\mathrm{x}$ inotropismo negativo) e semelhante aos dados de Otterstad et al. ${ }^{57}$ Convém lembrar que não houve diferença das variáveis em nenhum dos grupos em relação ao grupo CT.

Neste cenário fisiológico, as aferições da FC em repouso, antes do teste de esforço, mostraram aumento no grupo de simpatectomia bilateral. Yoshimoto et al. ${ }^{34}$ descreveram, na simpatectomia bilateral, queda significativa da FC em relação ao grupo sham. Neste mesmo estudo, quando acrescido o atenolol, o grupo sham respondeu com bradicardia, enquanto o grupo 
intervenção ficou inalterado. Em nosso estudo, o grupo atenolol apresentou FC mais baixa, mas sem significância estatística com o grupo controle, mesmo utilizando as maiores doses de droga encontradas na literatura ${ }^{39}$. Entretanto, comparada com o grupo BIL, a diferença é significativa, provavelmente pelos animais deste último grupo estarem mais taquicárdicos. No grupo UNIA, quando comparado ao UNI, há menor FC no grupo tratado com atenolol, mostrando a melhor ação do beta bloqueador somente nos animais simpatectomizados. Nossos achados sugerem que diante do estímulo adrenérgico periférico compensatório, o atenolol age melhor, talvez pela maior densidade de receptores $\beta 1$ demonstrada em nosso estudo (mesmo sem significância estatística).

Com relação à $\mathrm{PA}$, no trabalho de Yoshimoto et al., ${ }^{34}$ não houve diferença entre os grupos, mesmo após administração do atenolol. Jiang et al. ${ }^{35}$ descreveram valores significativamente menores de FC e PAM na simpatectomia química com 6-hidroxidopamina, comparados com os ratos controle. Contudo, convém esclarecer que o modelo de simpatectomia química com 6-hidroxidopamina leva à denervação sistêmica, inclusive renal, pela infusão peritoneal da droga. Mesmo se os modelos prévios de estudos isolados, sobre a ação da 6-hidroxidopamina na via simpática renal, sugerirem pouca alteração hemodinâmica, não há como afirmar a total ausência de interação entre essas variáveis. No já citado estudo de Perlini et al. ${ }^{52}$, comparando a simpatectomia química com 6-hidroxidopamina contra o propanolol, a doxazosina e o placebo em ratos com hipertrofia de VE por bandagem da aorta. Tal estudo não encontrou diferenças quanto à FC entre as 
drogas, ou placebo. Os animais bandados tinham PAS e PAD maiores em relação ao seu controle nas três drogas e inclusive no placebo. No modelo de simpatectomia química com guanetidina, Julien et al. ${ }^{58}$ não encontraram alterações na PA apenas na sua variabilidade, atribuindo a manutenção da PA à ativação do sistema renina-angiotensina-aldosterona. Em humanos, Lobato et $a l^{53}$ não encontraram diferenças entre $F C$ e PA, antes e após a simpatectomia por xylocaína unilateral esquerda ou direita em pacientes sem doença cardíaca. Nossos achados mostraram diferença da PA entre os grupos UNIA e BIL que pode ser inferida pela melhor ação do betabloquador diante do tônus simpático periférico aumentado, além de aumento de receptores $\beta 1$ encontrado nos animais submetidos ao procedimento, semelhante aos achados da FC.

Durante o esforço físico, estudo com cães comparando simpatectomia direita e esquerda ${ }^{59}$ demonstrou, no pico do esforço, o lado esquerdo com maior FC, seguido pelo controle e depois pelo lado direito. Neste mesmo estudo, o lado esquerdo ficou mais taquicárdico após o procedimento. O lado direito teve FC mais baixa, após o procedimento no repouso e no pico do esforço, além de menor capacidade ao exercício. Ao término do estudo, alguns animais foram submetidos à simpatectomia bilateral e comparados com o controle, que evidenciou menor FC e menor pressão sistólica intraventricular. Esses achados são compatíveis com o que seria esperado do ponto de vista fisiológico, considerando que o gânglio estrelado direito inerva predominantemente os átrios e estimula o nó sinusal e o átrio-ventricular (aumentando a FC e diminuindo a condução átrio-ventricular quando estimulado), 
enquanto o gânglio estrelado esquerdo inerva predominantemente os ventrículos, aumentando a força de contração e, consequentemente, a PA durante estímulo. Contudo, nosso estudo demonstrou aumento da atividade simpática nos grupos simpatectomizados e os animais que já eram mais taquicárdicos ao repouso tiveram incremento da FC ao esforço, permanecendo o grupo BIL com FC ainda maior. Acreditamos que, a despeito do maior tônus simpático neste grupo, não houve saturação dos receptores, permitindo o acréscimo da FC ao esforço. Não houve incremento dos níveis da PA ao esforço, o que poderia ser justificado pela diminuição do tempo de enchimento ventricular devido à taquicardia limitando, assim, sua elevação.

$\mathrm{Na}$ avaliação da modulação autonômica, Jiang et $a .^{35}$ encontraram menor variabilidade da FC tanto no domínio do tempo (SDNN, SDANN e RMSSD), quanto na frequência (BF, $A F$ e $B F / A F)$, inferindo que os ratos do grupo simpatectomia química tiveram dominância parassimpática. Nos estudos em humanos submetidos à simpatectomia bilateral, para tratamento de hiperhidrose, Cruz et al. ${ }^{60}$ verificaram aumento da atividade vagal e diminuição da atividade simpática, quando analisados por Holter, após seis meses do procedimento. Nossa análise demonstrou aumento da atividade parassimpática, expresso pela maior atividade da AF nos grupos CTAT, UNIA e BIL. O $\beta$-bloqueador leva ao aumento da atividade parassimpática, ${ }^{61}$ enquanto esta ação, no grupo BIL, foi atribuída a uma tentativa compensatória pelo aumento do tônus simpático periférico.

Quanto à expressão de receptores beta, em publicação avaliando os efeitos eletrofisiológicos da simpatectomia bilateral em ratos, Xie et al. ${ }^{62}$ 
demonstraram menor expressão de receptores $\beta 1$ por imunofluorescência do grupo simpatectomia, em relação ao sham, inferindo downregulation. Em modelo canino, comparando controle, simpatectomia química com 6-hidroxidopamina e simpatectomia cirúrgica, Valette et al. ${ }^{63}$ demonstraram maior expressão de receptores $\beta$ (upregulation) nas duas modalidades de simpatectomia (química aumento de 190\% e cirúrgica 219\%) avaliados por PET. Achados semelhantes foram publicados por Zhao e Muntz ${ }^{64}$ com upregulation de receptores $\beta 1$, mas não de $\beta 2$ na simpatectomia química por 6-hidroxidopamina. O tradicionalmente esperado, da regulação dos adrenoreceptores, seria um upregulation com o uso de betabloqueadores (exceto aqueles com atividade simpatomimética intrínseca que podem levar a downregulation) relacionado ao grau de seletividade, ou seja, upregulation de receptores $\beta 1 \mathrm{e}$ $\beta 2$ para os não seletivos e upregulation de receptores $\beta 1$ para os seletivos. ${ }^{65}$ Nos casos de tônus simpático cronicamente aumentado, como na IC, O esperado seria downregulation dos adreno-receptores $\beta$. Contudo, nas situações de isquemia miocárdica, há upregulation desses receptores, apesar da grande liberação de noradrenalina nesta situação. ${ }^{66} \mathrm{~A}$ literatura não é uniforme na metodologia de dosagem, nem de procedimento da simpatectomia. Nossos achados sugerem downregulation de $\beta 2$, e mesmo sem confirmação estatística, upregulation de $\beta 1$ no grupo BIL, o que pode inferir questões quanto à sensibilidade dos receptores às diferentes quantidades de catecolaminas. $O$ grupo BIL apresentou a maior quantidade de catecolaminas periféricas e respondeu com maior expressão de receptores $\beta 1$, enquanto o grupo UNI teve menor quantidade de catecolaminas periféricas e expressou menos 
receptores $\beta 1$, o que pode especular relação não linear entre concentração de catecolaminas e expressão de receptores beta.

No que se refere às catecolaminas, Yoshimoto et al. ${ }^{34}$ descreveram queda significativa na expressão de catecolaminas miocárdicas, nas quatro câmaras cardíacas na simpatectomia bilateral, em relação ao grupo sham. Entretanto, não foram avaliadas catecolaminas periféricas. Pardini et al. ${ }^{66}$ verificaram queda da noradrenalina em pelo menos $94 \%$ em todas as regiões do coração, mas não em tecido periférico na simpatectomia cirúrgica. Jiang et al..$^{35}$ descreveram queda de $72,7 \%$ na noradrenalina miocárdica no VE após simpatectomia química com 6-hidroxidopamina. Importante achado em nosso estudo foi o aumento expressivo das catecolaminas periféricas, corroborando a hipótese de via compensatória simpática extracardíaca, considerando que as catecolaminas miocárdicas não mostraram diferença entre os grupos.

Há poucos dados relacionados à análise tecidual após simpatectomia em modelos não patológicos. Jiang et al..$^{35}$ concluíram que a simpatectomia química induziu degeneração de cardiomiócitos com necrose e infiltração inflamatória focal, hiperplasia dos tecidos conectivos intersticiais, além de deposição de colágeno. Contudo, estes achados podem estar relacionados a provável efeito tóxico da 6-hidroxidopamina no miócito, como descrito previamente ${ }^{67}$ Nosso estudo analisou, exclusivamente, o tamanho do miócito e não encontrou diferença. Contudo, a metodologia da morfometria contempla a seleção de miócitos íntegros para esta medida. 
6. CONCLUSÃO 
Nosso estudo mostrou que, apesar da simpatectomia uni ou bilateral, ocorre manutenção do tônus simpático evidenciado pelo aumento de FC ao repouso e sustentada ao esforço, além de maiores valores de PA ao repouso. Esta resposta ocorre provavelmente por maiores concentrações de catecolaminas periféricas. Estes achados sugerem a possibilidade de uma via de compensação simpática extracardíaca. Observamos, ainda, upregulation de receptores $\beta 1$ no grupo BIL que pode justificar o aumento à resposta ao maior nível circulante de catecolaminas, promovendo assim maior FC e PA. Além disso, esse upregulation pode ter disponibilizado mais receptores $\beta 1$ para ação do betabloqueador como observado na melhor resposta nos níveis de PA e FC no grupo UNIA. Estudos adicionais que superem as limitações da atual proposta podem auxiliar na confirmação desta tese. Convém aguardar maiores esclarecimentos do impacto fisiológico da simpatectomia, antes de considerá-la no cenário clínico. 
7. LIMITAÇÕES DO ESTUDO 
A alta taxa de mortalidade do grupo bilateral limitou a quantidade de dados disponíveis para a análise. A principal causa de mortalidade no procedimento deve-se a hematoma, lesão vascular e pneumotórax. ${ }^{68} \mathrm{O}$ uso da ketamina pode estar associado à estimulação simpática, o que pode interferir em alguns dos resultados.

A confirmação clínica pela ptose palpebral ipsilateral (síndrome de Horner) não necessariamente se correlaciona com o grau de denervação simpática cardíaca, mas indica somente o bloqueio das fibras que atravessam a parte superior do gânglio estrelado ${ }^{68}$ e foi o sinal físico utilizado no modelo que consagrou o método. ${ }^{38}$ Acreditamos na completa denervação cardíaca, considerando que o dano da esclerose foi extenso no plexo nervoso e que $90 \%$ dos animais tinham algum grau de paresia no membro superior ipsilateral ao procedimento. Este fator poderia ser considerado limitante, mas não houve diferença no desempenho do teste de esforço, comparando com animais controle nas variáveis tempo, velocidade e distância. 
8. REFERÊNCIAS 
1. Maehle AH. "Receptive Substances": John Newport Langley (1852-1925) and his path to a receptor theory of drug action. Med Hist. 2004;48:15374.

2. Cannon W. Bodily changes in pain, hunger, fear and rage. New York: Littleton, 1929, p. 404.

3. Zipes DP. Heart-brain interactions in cardiac arrhythmias: role of the autonomic nervous system. Cleve Clin J Med. 2008;75(Suppl 2):S94-6.

4. Pierpont GL, DeMaster EG, Reynolds S, Pederson J, Cohn JN. Ventricular myocardial catecholamines in primates. J Lab Clin Med. 1985;106:205-10.

5. Lyon AR, Rees PSC, Prasad S, Poole-Wilson PA, Harding SE. Stress (Takotsubo) cardiomyopathy - a novel pathophysiological hypothesis to explain catecholamine-induced acute myocardial stunning. Nature 2008;5:22-29.

6. Triposkiadis F, Karayannis G, Giamouzis G, Skoularigis J, Louridas G, Butler J. The sympathetic nervous system in heart failure physiology, pathophysiology, and clinical implications. $J A m$ Coll Cardiol. 20093;54(19):1747-62.

7. Rozec B, Erfanian M, Laurent K, Trochu JN, Gauthier C. Nebivolol, a vasodilating selective beta (1)-blocker, is a beta (3)-adrenoceptor agonist in the nonfailing transplanted human heart. $J A m$ Coll Cardiol 2009;53:1532-8. 
8. Feldman DS, Carnes CA, Abraham WT, Bristow MR. Mechanisms of disease: beta-adrenergic receptors-alterations in signal transduction and pharmacogenomics in heart failure. Nat Clin Pract Cardiovasc Med. 2005;2:475-83.

9. Woodcock EA, Du XJ, Reichelt ME, Graham RM. Cardiac alpha1adrenergic drive in pathological remodelling. Cardiovasc Res. 2008;77:452-62.

10. Grassi G, Cattaneo BM, Mancia G. Sympathetic nervous system. In: Poole-Wilson PA, Colucci WS, Massie BM, Chatterjee K, Coats AJ, eds. Heart failure: scientific principles and clinical practice. New York: Churchill Livingstone;1997:199-214.

11. Mancia G, Bousquet P, Elghozi JL, Esler M, Grassi G, Julius S, Reid J, Van Zwieten PA. The sympathetic nervous system and the metabolic syndrome. J Hypertens. 2007;25:909-20.

12. Jordan J, Grassi G. Adrenergic overdrive: a "not-so-sympathetic" risk factor in renal failure patients. $J$ Hypertens. 2007;25:1197-9.

13. Packer M, Bristow MR, Cohn JN, Colucci WS, Fowler MB, Gilbert EM, Shusterman $\mathrm{NH}$. The effect of carvedilol on morbidity and mortality in patients with chronic heart failure. N Engl J Med. 1996;334:1349-55.

14. The CIBIS-II investigators and committees. The cardiac insufficiency bisoprolol study II (CIBIS-II): a randomized trial. Lancet. 1999;353:9-13. 
15. MERIT-HF study group. Effect of metropolol $\mathrm{CR} / \mathrm{XL}$ in chronic heart failure: metoprolol $\mathrm{CR} / \mathrm{XL}$ randomized intervention trial in congestive heart failure (MERIT-HF). Lancet. 1999;353:2001-7.

16. Packer M, Fowler MB, Roecker EB, Coats AJ, Katus HA, Krum H, Mohacsi P, Rouleau JL, Tendera M, Staiger C, Holcslaw TL, Amann-Zalan I, DeMets DL. Effect of carvedilol on the morbidity of patients with severe chronic heart failure. Results of the carvedilol prospective randomized cumulative survival (COPERNICUS) study. Circulation. 2002;106:2194-9.

17. Dargie HJ. Effect of carvedilol on outcome after myocardial infarction in patients with left ventricular dysfunction: the CAPRICORN randomized trial. Lancet 2001;357:1385-90.

18. Abraham WT, De Ferrari GM. Novel non-pharmacological approaches to heart failure. J Cardiovasc Transl Res. 2014;7:263-5.

19. Patel HC, Rosen SD, Lindsay A, Hayward C, Lyon AR, di Mario C. Targeting the autonomic nervous system: measuring autonomic function and novel devices for heart failure management. Int $J$ Cardiol. 2013;170:107-17.

20. Gronda E, Lovett EG, Tarascio M, Georgakopoulos D, Grassi G, Vanoli E. The baroreceptor as a therapeutic target for heart failure. $J$ Cardiovasc Transl Res. 2014;7:301-9.

21. Florea VG, Cohn JN. The autonomic nervous system and heart failure. Circ Res. 2014;114:1815-26. 
22. Zile MR, Abraham WT, Weaver FA, Butter C, Ducharme A5, Halbach M, Klug D, Lovett EG, Müller-Ehmsen J, Schafer JE, Senni M, Swarup V, Wachter R, Little WC. Baroreflex activation therapy for the treatment of heart failure with a reduced ejection fraction: safety and efficacy in patients with and without cardiac resynchronization therapy. Eur $J$ Heart Fail. 2015;17:1066-74.

23. De Ferrari GM. Vagal stimulation in heart failure. J Cardiovasc Transl Res. 2014;7:310-20.

24. Zannad F, De Ferrari GM, Tuinenburg AE, Wright D, Brugada J, Butter C, Klein H, Stolen C, Meyer S, Stein KM, Ramuzat A, Schubert B, Daum D, Neuzil P, Botman C, Castel MA, D'Onofrio A, Solomon SD, Wold N, Ruble SB. Chronic vagal stimulation for the treatment of low ejection fraction heart failure: results of the NEural Cardiac TherApy foR Heart Failure (NECTAR-HF) randomized controlled trial. Eur Heart J. 2015;36(7):42533.

25. Premchand RK, Sharma K, Mittal S, Monteiro R, Dixit S, Libbus I, DiCarlo LA, Ardell JL, Rector TS, Amurthur B, KenKnight BH, Anand IS. Autonomic regulation therapy via left or right cervical vagus nerve stimulation in patients with chronic heart failure: results of the ANTHEMHF trial. J Card Fail. 2014;20(11):808-16. 
26. Gold MR, Van Veldhuisen DJ, Hauptman PJ, Borggrefe M, Kubo SH, Lieberman RA, Milasinovic G, Berman BJ, Djordjevic S, Neelagaru S, Schwartz PJ, Starling RC, Mann DL. Vagus nerve stimulation for the treatment of heart failure: the INOVATE-HF Trial. J Am Coll Cardiol. 2016;68(2):149-58.

27. Lopshire JC, Zipes DP. Spinal cord stimulation for heart failure: preclinical studies to determine optimal stimulation parameters for clinical efficacy. $J$ Cardiovasc Transl Res. 2014;7:321-9.

28. Shen MJ, Zipes DP. Interventional and device-based autonomic modulation in heart failure. Heart Fail Clin. 2015;11(2):337-48.

29. Taborsky M. The effect of renal denervation in patients with advanced heart failure: the OLOMOUC I study. Presented at: European Society of Cardiology Congress; August 27, 2012; Munich, Germany.

30. Davies JE, Manisty $\mathrm{CH}$, Petraco R, Barron AJ, Unsworth B, Mayet J, Hamady M, Hughes AD, Sever PS, Sobotka PA, Francis DP. First-in-man safety evaluation of renal denervation for chronic systolic heart failure: primary outcome from REACH-Pilot study. Int J Cardiol. 2013;162:189-92.

31. Bohm M. Renal denervation in patients with chronic heart failure. ClinicalTrials.gov Identifier: NCT02085668. https://clinicaltrials.gov/ct2/show/results/NCT02085668

32. Leriche R. Surgery of the sympathetic at the level of the extremities. Progr Med (Paris). 1955;83:75-6. 
33. Conceição-Souza GE, Pêgo-Fernandes PM, Cruz Fd, Guimarães GV, Bacal F, Vieira ML, Grupi CJ, Giorgi MC, Consolim-Colombo FM, Negrão CE, Rondon MU, Moreira LF, Bocchi EA. Left cardiac sympathetic denervation for treatment of symptomatic systolic heart failure patients - a pilot study. Eur J Heart Fail. 2012;14:1366-73.

34. Yoshimoto M, Wehrwein EA, Novotny M, Swain GM, Kreulen DL, Osborn JW. Effect of stellate ganglionectomy on basal cardiovascular function and responses to beta1-adrenoceptor blockade in the rat. Am J Physiol Heart Circ Physiol. 2008;295:H2447-54.

35. Jiang $Y H$, Jiang $P$, Yang JL, Ma DF, Lin HQ, Su WG, Wang Z, Li X. Cardiac dysregulation and myocardial injury in a 6-hydroxydopamineinduced rat model of sympathetic denervation. PLOS One. 2015;10(7):e0133971.

36. Colégio Brasileiro de Experimentação Animal (COBEA). In: http://www.cobea.org.br/index.php.

37. Science in the Service of animal Welfare. In: http://www.ufaw.org.uk/

38. Abdi S, Yang Z. A novel technique for experimental stellate ganglion block in rats. Anesth Analg. 2005;101:561-5. 
39. Andreo VC. Estudo dos efeitos de injeção intravascular de drogas vasoconstritoras, presentes nas soluções anestésicas locais, sobre a pressão arterial de ratos normotensos, hipertensos renais um-rim, um clip $(1 R-1 C)$ e $1 R-1 C$ tratados com atenolol. Dissertação (mestrado) Faculdade de Odontologia de Bauru. Universidade de São Paulo, 2010.

40. Soares PP, da Nóbrega AC, Ushizima MR, Irigoyen MC. Cholinergic stimulation with pyridostigmine increases heart rate variability and baroreflex sensitivity in rats. Auton Neurosci. 2004;113(1-2):24-31.

41. Mostarda C, Rogow A, Silva IC, De La Fuente RN, Jorge L, Rodrigues B, Heeren MV, Caldini EG, De Angelis K, Irigoyen MC. Benefits of exercise training in diabetic rats persist after three weeks of detraining. Auton Neurosci. 2009;145(1-2):11-6.

42. Brooks GA, White TP. Determination of metabolic and heart rate responses of rats to treadmill exercise. J Appl Physiol. 1978;45(6):100915.

43. Livak KJ, Schmittgen TD. Analysis of relative gene expression data using real-time quantitative PCR and the 2(-Delta Delta $\mathrm{C}(\mathrm{T})$ ) method. Methods. $2001 ; 25(4): 402-8$.

44. Sato S, Nomura S,Kawano F, Tanihata J,Tachivashiki K, Imaizumi K. Effects of the $\beta 2$-agonist clenbuterol on $\beta 1$ - and $\beta 2$-adrenoceptor mRNA expression of rat skeletal and left ventricle muscle. J Pharmacol Sci. 2008; 107, 393-400. 
45. Bai J, Meng Z. Expression of apoptosis-related genes in livers from rats exposed to sulfur dioxide. Toxicology. 2005;216(2-3):253-60.

46. Yüzbasioglu A, Onbasilar I, Kocaefe C, Ozgüç M. Assessment of housekeeping genes for use in normalization of real time PCR in skeletal muscle with chronic degenerative changes. Exp Mol Pathol. 2010;88(2):326-9.

47. Yanowitz F, Preston JB, Abildskov JA. Functional distribution of right and left stellate innervation to the ventricles. Production of neurogenic electrocardiographic changes by unilateral alteration of sympathetic tone. Circ Res. 1966;18(4):416-28.

48. Schwartz PJ, Priori SG, Cerrone M, Spazzolini C, Odero A, Napolitano C, Bloise R, De Ferrari GM, Klersy C, Moss AJ, Zareba W, Robinson JL, Hall WJ, Brink PA, Toivonen L, Epstein AE, Li C, Hu D. Left cardiac sympathetic denervation in the management of high-risk patients affected by the long-QT syndrome. Circulation. 2004;109:1826-33.

49. Collura CA, Johnson JN, Moir C, Ackerman MJ. Left cardiac sympathetic denervation for the treatment of long QT syndrome and catecholaminergic polymorphic ventricular tachycardia using video-assisted thoracic surgery. Heart Rhythm. 2009;6(6):752-9.

50. Schlack W, Schafer S, Thamer V. Left stellate ganglion block impairs left ventricular function. Anesth Analg. 1994;79:1082-8. 
51. Müllenheim J, Preckel B, Obal D, Heiderhoff M, Hoff J, Thämer V, Schlack W. Left stellate ganglion block has only small effects on left ventricular function in awake dogs before and after induction of heart failure. Anesth Analg. 2000;91(4):787-92.

52. Perlini S, Ferrero I, Palladini G, Tozzi R, Gatti C, Vezzoli M, Cesana F, Janetti MB, Clari F, Busca G, Mancia G, Ferrari AU. Survival benefits of different antiadrenergic interventions in pressure overload left ventricular hypertrophy/failure. Hypertension. 2006;48:93-7.

53. Lobato EB, Kern KB, Paige GB, Brown M, Sulek CA. Differential effects of right versus left stellate ganglion block on left ventricular function in humans: an echocardiographic analysis. J Clin Anesth. 2000;12:315-8.

54. Schlack W, Dinter W. Haemodynamic effects of a left stellate ganglion block in ASA 1 patients: an echocardiographic study. Eur $J$ Anaesth. 1999;17:79-84.

55. Cruz JM, Fonseca M, Pinto FJ, Oliveira AG, Carvalho LS. Cardiopulmonary effects following endoscopic thoracic sympathectomy for primary hyperhidrosis. Eur J Cardiothorac Surg. 2009;36:491-6.

56. Gonzenbach R, Satz N, Vetter W, Jenni R, Krayenbühl HP. Left ventricular function in hypertension treated with beta blockers. Schweiz Med Wochenschr. 1978;108(44):1710-2. 
57. Otterstad JE, Froeland G, Erikssen J. Left ventricular end-diastolic dimensions measured at the $\mathrm{P}$ wave and $\mathrm{Q}$ wave during a randomized, double-blind one-year follow-up study comparing the effect of atenolol vs. hydrochlorothiazide + amiloride on blood pressure in men with mild to moderate hypertension. Scand J Clin Lab Invest. 1993;53(2):155-62.

58. Julien C, Kandza P, Barres C, Lo M, Cerutti C, Sassard J. Effects of sympathectomy on blood pressure and its variability in conscious rats. Am J Physiol. 1990;259(5 Pt 2):H1337-42.

59. Schwartz PJ, Stone HL. Effects of unilateral stellectomy upon cardiac performance during exercise in dogs. Circ Res. 1979;44(5):637-45.

60. Cruz J, Sousa J, Oliveira AG, Carvalho LS. Effects of endoscopic thoracic sympathectomy for primary hyperhidrosis on cardiac autonomic nervous activity. J Thorac Cardiovasc Surg. 2009;137:664-9.

61. Cook JR, Bigger JT Jr, Kleiger RE, Fleiss JL, Steinman RC, Rolnitzky LM. Effect of atenolol and diltiazem on heart period variability in normal persons. J Am Coll Cardiol. 1991;17(2):480-4.

62. Xie X, Visweswaran R, Guzman PA, Smith RM, Osborn JW, Tolkacheva EG. The effect of cardiac sympathetic denervation through bilateral stellate ganglionectomy on electrical properties of the heart. Am J Physiol Heart Circ Physiol. 2011;301:H192-9. 
63. Valette H, Deleuze P, Syrota A, Delforge J, Crouzel C, Fuseau C, Loisance D. Canine myocardial beta-adrenergic, muscarinic receptor densities after denervation: a PET study. J Nucl Med. 1995;36:140-6.

64. Zhao M, Muntz KH. Differential downregulation of 32-adrenergic receptors in tissue compartments of rat heart is not altered by sympathetic denervation. Circ Res. 1993;73:943-51.

65. Haeusler G. Pharmacology of beta-blockers: classical aspects and recent developments. J Cardiovasc Pharmacol. 1990;16(Suppl 5):S1-9.

66. Pardini BJ, Lund DD, Schmid P. Innervation patterns of the middle cervical stellate ganglion complex in the rat. Neurosci Lett. 1990;117: 300-6.

67. Lurie KG, Bristow MR, Minobe WA, Masek M, Billingham ME. 6-hydroxydopamine mediated cardiotoxicity in rabbits. Am J Cardiovasc Pathol. 1988;2(2):181-91.

68. Gulcu N, Gonca E, Kocoglu H. A lateral percutaneous technique for stellate ganglion blockade in rats. Anesth Analg. 2009;108:1701-4. 